http://kitaibelia.unideb.hu/

ISSN 2064-4507 (Online) • ISSN 1219-9672 (Print)

(C) Department of Botany, University of Debrecen, Hungary

25(1): 33-56.; 2020

DOI: $10.17542 /$ kit.25.33

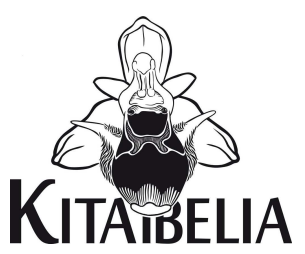

\title{
Florisztikai adatok a Tokaj-Zempléni-hegyvidékről és környékéről
}

\author{
TÜRKE Ildikó J.1 ${ }^{1}$ LONTAY László1, SERFőZŐ József ${ }^{1}$, ZsólyOMI Tamás², \\ DROZD Attila ${ }^{1}$ \& PELLES Gábor ${ }^{3}$
}

(1) Aggteleki Nemzeti Park Igazgatóság H-3758 Jósvafő, Tengerszem oldal 1.

(2) Tokaji Természetvédelmi Egyesület H-3910 Tokaj, Klapka u. 47.

(3) Sátoraljaújhely, H-3980 Munkácsy M. u. 26. fsz.2.

\section{Floristic data from the Tokaj-Zemplén Mts and the surroundings (NE Hungary)}

\begin{abstract}
In our paper, we publish the most important new floristic data from the region of Tokaj Hills and Zemplén Mountains (incl. Szerencsköz, Hernád-mente, Bodrogköz, Tatkaköz, Harangod) from the last ten years. During this period, we discovered two new protected species (Asplenium javorkaeanum, Epipactis nordeniorum) in the Zemplén Mountains and seven new protected species (Cephalanthera damasonium, Cirsium brachycephalum, Epilobium palustre, Epipactis palustris, Lycopodium clavatum, Pyrola rotundifolia, Polystichum aculeatum) in the Hungarian part of Bodrogköz. We found new locations of several rare species (Epipactis exilis, Dryopteris expansa, Blechnum spicant, Androsace maxima, Orchis coriophora, Orchis purpurea, Dactylorhiza sambucina, Sonchus palustris, Cicuta virosa). We confirmed the occurrence of four species, which have not been detected for decades (Sedum hispanicum, Erysimum wittmannii subsp. pallidiflorum, Pseudolysimachion spurium, Botrychium lunaria).
\end{abstract}

Keywords: distribution, North Hungarian Mountains, occurrence data, protected species, vascular flora

Összefoglalás - Cikkünkben a Tokaj-Zempléni-hegyvidék területéről és környékéről (a Szerencsközből, a Hernád-mentéről, a Bodrogközből, a Taktaközből és a Harangodból) az elmúlt évtized legfontosabb és legérdekesebb florisztikai eredményeiről számolunk be. A Zempléni-hegységből két új védett fajt (Asplenium javorkaeanum, Epipactis nordeniorum), a Bodrogköz magyarországi részéről pedig hét új védett fajt mutattunk ki (Cephalanthera damasonium, Cirsium brachycephalum, Epilobium palustre, Epipactis palustris, Lycopodium clavatum, Pyrola rotundifolia, Polystichum aculeatum). Számos ritka faj új lelőhelyére bukkantunk (Epipactis exilis, Dryopteris expansa, Blechnum spicant, Androsace maxima, Orchis coriophora, Orchis purpurea, Dactylorhiza sambucina, Sonchus palustris, Cicuta virosa). Továbbá sikerült megerősítenünk több olyan faj adatát, amelyek már évtizedek óta nem kerültek elő (Sedum hispanicum, Erysimum wittmannii subsp. pallidiflorum, Pseudolysimachion spurium, Botrychium lunaria).

Kulcsszavak: edényes flóra, elterjedés, előfordulási adatok, Északi-középhegység, védett fajok

\section{Bevezető}

Az 1870-es évek jeles botanikusa, Simkovics (1877) így fogalmaz: „a Tokaj-Hegyalja növényzete új leletek által is megjutalmazza a figyelmes fúvész kutatásait”, ami éppúgy érvényes a területet botanikus szemmel először járó Kitaibelre, mint napjainkban az itt megforduló szakemberekre.

Közleményünkben az elmúlt évtized során az Aggteleki Nemzeti Park Igazgatóság Zemp- 
léni Tájegysége területéről, vagyis a Hernád, a Tisza és a szlovák-magyar határ által közrezárt területről gyújtött legfontosabb florisztikai adatainkról számolunk be. Adatokat közlünk főként a Hegyalja, a Tokaji-hegy, az Abaúji-Hegyalja, a Szerencsi-dombság, a Hegyközidombság és a Központi-Zemplén területéről, kisebb számban a Zempléni-hegységgel szomszédos Szerencsközből, a Hernád-mentéről, a Bodrogközből, a Taktaközből és a Harangodból. A területről összegyűlt további fontos adatokról egy külön cikket álítottunk össze, ahol főként a Magyar Flóratérképezési Adatbázisból (BARTHA et al. 2015 [1]) hiányzó előfordulásokat közöljük (TÜRKE et al. 2020).

Közleményünkben elsősorban védett és fokozottan védett fajok korábban ismeretlen adatait közöljük, illetve néhány esetben ezek évtizedekkel ezelőtti adatainak aktuális megerősítését. Azoknál a fajoknál, ahol az általunk gyűjtött előfordulási adatok sokaságát terjedelmi okokból nem állt módunkban mind felsorolni, ott csak azokat az adatokat vettük fel az enumerációba, amelyek a Magyar Flóratérképezési Adatbázisra (BARTHA et al. 2015, [1]) nézve alapmező szintjén újak.

Az adatokat a fajok alfabetikus sorrendjében, tájanként külön szakaszban közöljük. A nevezéktan KIRÁLY (2009) munkáját követi. A településekhez tartozó földrajzi nevek tekintetében az Aggteleki Nemzeti Park Igazgatóság dűlőkataszteri térképét vettük alapul [2], továbbá néhány esetben az EOTR 1:10000 topográfiai térképek földrajzi elnevezéseivel pontosítottuk az előfordulások helyét. A fajok részletezésénél - ahol szükséges volt megemlíteni - a természetföldrajzi szempontból helyesebb Tokaj-Zempléni-hegyvidék helyett a köznyelvben elterjedtebb Zempléni-hegység elnevezést használjuk, több, a területről publikáló szerzőhöz hasonlóan (pl. Simon 2005a,b, MolnÁR V. et al. 2000, PifKó et al. 2003). Az egyes fajok részletezésénél feltüntettük az adatgyüjtő monogramját, valamint a Közép-Európai Flóratérképezés módszertana (NIKLFELD 1971) szerinti kvadrátszámokat is.

Az irodalmi források tekintetében igyekeztünk minél teljesebb listát közölni az egyes fajoknál, ahol azonban túl sok forrás és adat állt rendelkezésünkre, ott csak azokat emeltük ki, illetve részleteztük, amelyeket az adott fajnál a legfontosabbnak ítéltünk a saját adatainkkal való összevethetőség szempontjából. A terület korábbi irodalma mellett több herbárium digitálisan hozzáférhető Borsod-Abaúj-Zemplén megyei anyagát is átnéztük (E. VojTKó et al. 2014, TAKÁCS et al. 2014, 2015, NAGY et al. 2016, NóTÁRI et al. 2017 alapján). A herbáriumi adatok közül azokat közöljük, amelyeket fontosságuk megkövetel, így pl. teljes adatsort közlünk abban az esetben, ha irodalmi forrás nem áll rendelkezésünkre, a legtöbb faj esetében azonban csak a publikációkban nem szereplő előfordulásokat soroljuk fel. Néhány fontosabb fajról herbáriumi példányt őrzünk, illetve az adatok egy részét fotókkal dokumentáltuk.

Az adatsorban használt rövidítések:

$\begin{array}{llll}\text { Adatközlők } & \text { KJ: } & \text { Kóra Judit } \\ \text { BA: } & \text { Bereczki Attila } & \text { LL: } & \text { Lontay László } \\ \text { BI: } & \text { Béres István } & \text { PG: } & \text { Pelles Gábor } \\ \text { BS: } & \text { Barati Sándor } & \text { PZ: } & \text { Petrovics Zoltán } \\ \text { DA: } & \text { Drozd Attila } & \text { SJ: } & \text { Serfóző József } \\ \text { FB: } & \text { Fakla Béla } & \text { SuJ: } & \text { Sulyok József } \\ \text { FR: } & \text { Farkas Roland } & \text { SZA: } & \text { Sztuhai Anett } \\ \text { FNSZ: Füssi-Nagy Szabolcs } & \text { SZZS: } & \text { Szegedi Zsolt } \\ \text { HF: Herceg Ferenc } & \text { TH: } & \text { Thomas Haberler } \\ \text { HA: } & \text { Huber Attila } & \text { TP: } & \text { Tóth Péter } \\ \text { HaA: } & \text { Halász Antal } & \text { VV: } & \text { Virók Viktor } \\ \text { TIJ: } & \text { Türke Ildikó Judit } & \text { VR: } & \text { Verbinyecz Róbert } \\ & & \text { ZST: } & \text { Zsólyomi Tamás }\end{array}$

TMO: Aggteleki Nemzeti Park Zempléni Tájegység Természetmegőrzési Osztály munkatársai 2014-ben: Türke Ildikó J. Fakla Béla Zsólyomi Tamás Éles Eszter Sztuhai Anett 
Herbáriumok

DE-Soó: Debreceni Egyetem Soó Rezső Herbáriuma, Debrecen

DE-Siroki: Debreceni Egyetem Siroki Zoltán Herbáriuma, Debrecen

BPU: Eötvös Loránd Tudományegyetem Herbáriuma, Füvészkert, Budapest

EGR: Eszterházy Károly Egyetem Herbáriuma, Eger

GK: Pannon Egyetem Georgikon Kar Herbáriuma, Keszthely

BP: Magyar Természettudományi Múzeum, Növénytár, Budapest

HTIJ: Türke Ildikó Judit magángyűjteménye, Erdőbénye

\section{Enumeráció}

Tokaj-Zempléni-hegyvidék

(Tokaji-hegy, Hegyalja, Abaúji-Hegyalja, Központi-Zemplén,

Szerencsi-dombság, Hegyközi-dombság), Szerencsköz, Hernád-völgy

Allium paniculatum L. - Herb.: Takács (2010): Abaújszántó (DE-Soó). Lit.: KiSs (1939) és újabban MolnÁR \& TÜRKE (2007): Bodrogkisfalud, Szegilong. Ined.: Tállya: Palota-hegy, lejtősztyeppben [7793.3] (TIJ 2014, HTIJ).

Androsace maxima L. - $\underline{\text { Herb.: }}$ Soó (1951): Tarcal. Lit.: FARKAS (1999) Tarcal határából, VIRóK et al. (2004) a tállyai Patócs-hegyről írja. Ined.: Mezőzombor: Sós-dűlő (ZST 2014), Királytető, szőlőparlagok között kőtörmelékes helyen [7893.2] (TMO 2015).

Aquilegia vulgaris L. - Herb.: Hulják (1938): Erdőbényén, a Nagy-Mondoha D-i oldalán a szőlők feletti cserjésben találta (DE-Soó), bár itt valószínűleg kivadulásról lehetett szó, a faluban ugyanis kedvelt dísznövény. Vida (1957): Telkibánya felé a Nagy-völgyben gyűjtötte (EGR). Lit.: KISS (1939) a Tokár-tetőről írja sziklás helyről, ritkás bükkösből. SıMON (1974) az újhutai Flórika-forrás mellől említi. Újabban PATALENSZKY (2012) Baskón a Gazsóréten találta meg. Ined.: A Zempléni-hegységben is ritkának számító faj, több újabb őshonos előfordulása került elő. Regéc: Vajda-völgy fenyő elegyes bükkös tisztásának szélén [7594.3] (LL 2011); Nyíri: Vörös-víz-oldal tisztás szélén [7494.3] (LL 2012); Füzér: Piszkés-tető cserjésedő útrézsűben [7494.4] (LL 2012).

Asplenium adiantum-nigrum L. - Lit.: HAZSLINSZKY (1866): Tolcsva, Erdőbénye környéke. FARKAS (1999): Gecej-tető (helyesen Abaújszántó, Gejec-tető). Ined.: Tokaj: Lencsés-árok [7894.3] (ZST 2007).

Asplenium javorkaeanum Vida - A Zempléni-hegységre új! Lit.: Legközelebbi adata az Aggteleki-karsztról (Tornanádaska: Alsó-hegy) származik (FARKAS 1999), ahonnan azonban az utóbbi években valószínűleg eltűnt (VIRóK et al. 2016). Ined.: Tarcal: Turzó-dűlő, mesterséges kő támfalak üregeiben [7894.3] (ZST 2017). Megjelenése meglepő, hiszen egy alapvetően meszes alapkőzethez kötődő fajról van szó. A határozásban segítségünkre volt Sramkó Gábor (Debrecen).

Aster sedifolius L. - A részletes feltárómunkának köszönhetően közöljük a faj pontos hegyaljai elterjedési térképét (1. ábra). Munkánk során azt tapasztaltuk, hogy a réti őszirózsa a szőlőparlagok első megtelepedői között van, és a Hegyalján általánosan elterjedt faj. Herb.: Siroki (1954): Sárospatak (DE-Siroki). Lit.: Számos adatát közölték már korábban a Hegyaljáról (pl. Kiss 1939, Soó \& HARGITAi 1940, FARKAS 1999, PIFKó et al. 2003, MolnÁR \& TÜRKE 2007, Marschall \& Tuba 2009, MolnáR et al. 2016). Ined.: Tállya: Bojták, Fördős-tető, Nyírjes, Koldu szőlők; Mád: Sarkad-hegy, Hintós, Kis-hegyek; Rátka: Herceg-köves-hegy [7793.4] (TIJ 2015); Szegi: Somos, Cigány-hegy, Murány-dűlő [7794.3] (TIJ, FB 2014); Olaszliszka: Sajgó, Kulcsár, Lókötő-dűlő; Erdőbénye: Omlás, Hangyás-Mogyorós, Becski földek [7794.1] (TIJ, FB 2014); Tolcsva: Elő-hegy, Bartalos, Gyopáros, Vár-hegy, Serédi-dűlo, Nyakvágó, Ciróka, Mandulás; Sárazsadány: Szár-hegy dűlő; Vámosújfalu: Rány-tető 
[7794.2] (TIJ, FB, BA 2015); Erdőhorváti: Szőlők alja [7694.4] (FB 2015); Sátoraljaújhely: Somlyód, Bessenyei-oldal [7695.2] (TIJ 2015).

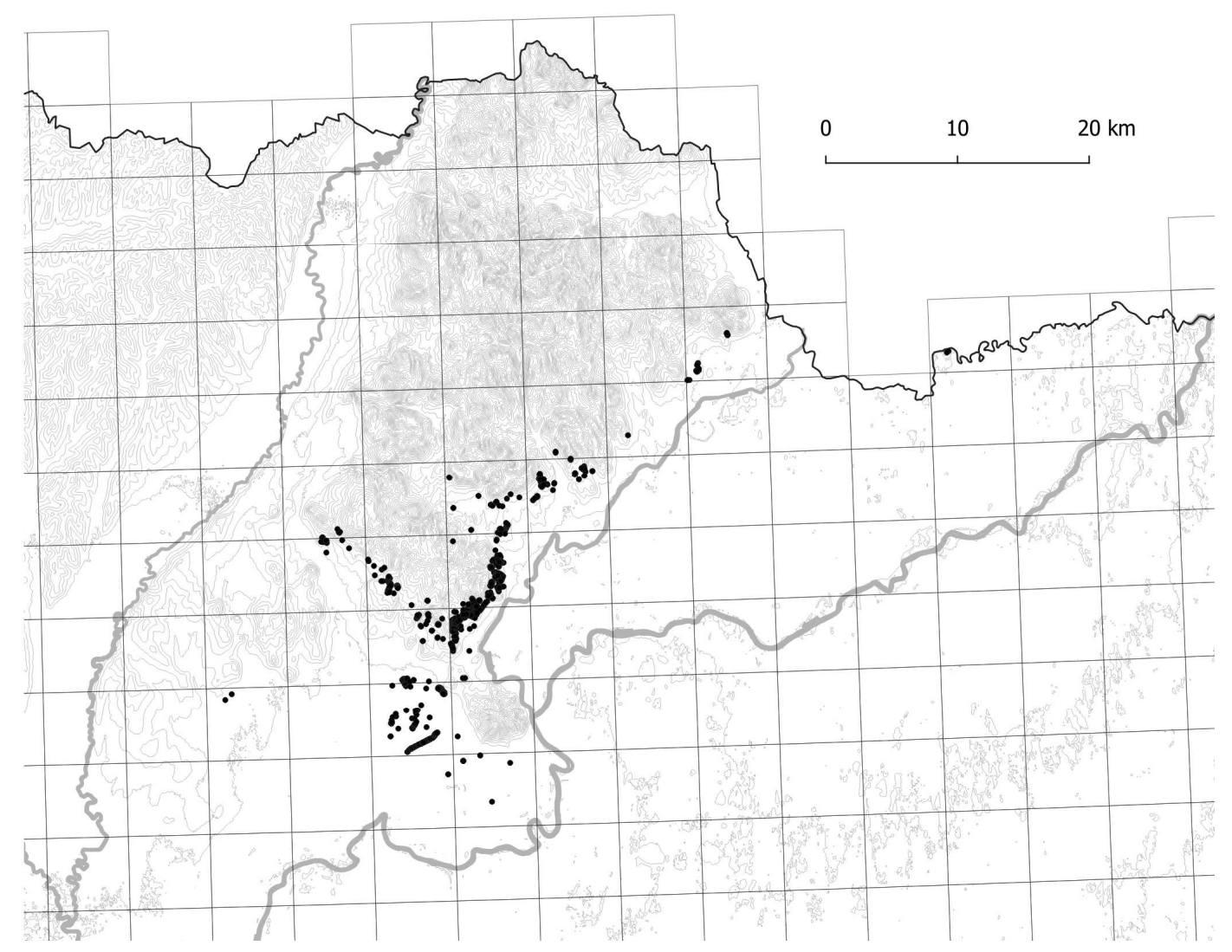

1. ábra Az Aster sedifolius elterjedése a vizsgált területen

Fig. 1 Distribution of Aster sedifolius on the study area

Asyneuma canescens (Waldst. et Kit.) Griseb. et Schenk - Szórványos előfordulású faj a Hegyalján. Herb.: Hulják (1936): Szerencs; Soó (1948): Abaújszántó (DE-Soó); Siroki (1943): Abaújszántó (DE-Siroki); Isépy (1962): Abaújszántó (BPU). Lit.: Elsőként HAZSLISZKY (1864, 1866) említi Abaújszántóról, Tokajból és Tolcsváról, pontosabb helymegjelölés nélkül. Később LAKATOS (1975) a „Szerencsi-szigethegységből” (Szerencsi-dombságból) Szentistvánbaksa Bika-rétről írja le (FARKAS 2010). SIMON (2005b) a boldogkőváraljai Tekeres-völgyből említi. Újabban BARATI et al. (2009) a Monoki Ốr-hegyről, MolNÁR et al. (2016) Abaújszántóról közli. Ined.: Tállya: Dorgó-tető [7793.4] (ZST 2011); Legyesbénye: Fuló-hegy [7892.2] (KJ 2013); Bekecs: Nagy-hegy [7893.1] (KJ 2013). Jó állapotú lejtősztyepp gyepekben.

Blechnum spicant (L.) Roth - Hazánkban sokáig csak az Alpokaljáról volt ismert. Lit.: Legközelebbi előfordulása Kassabéla mellől ismert (FuTÁK 1966). A Zempléni-hegységből először Halász Antal publikálta a faj Ördög-völgy feletti előfordulását (HALÁsz 2008), majd 2016ban a Borindzásról is előkerült (KÁLLAYNÉ 2018). Ined.: Regéc: Harasztos letermelt fenyves alatt, nyíresedő vágásterületen [7594.3] (SZZS 2007); Nagyhuta: Pap-hegy útrézsűben, mészkerülő bükkös szélén [7594.4] (SZZS 2008).

Botrychium lunaria (L.) Sw. - Herb.: Vajda (1948): Nagyhuta: Kőkapu, Határ-völgy, Komlóska-völgy (BP). Azóta nem került elő. Legközelebb a Zempléni-hegység szlovák területein (FutÁK 1966), a Bükkben (Molnár et al. 2016) és Aggteleken (PenksZA \& SAlAmon 1997, 
VIRóK et al. 2016) fordul elő. Ined.: Nagyhuta: Kékszűrő kisavanyodó gyepben [7695.1] (PG 2009).

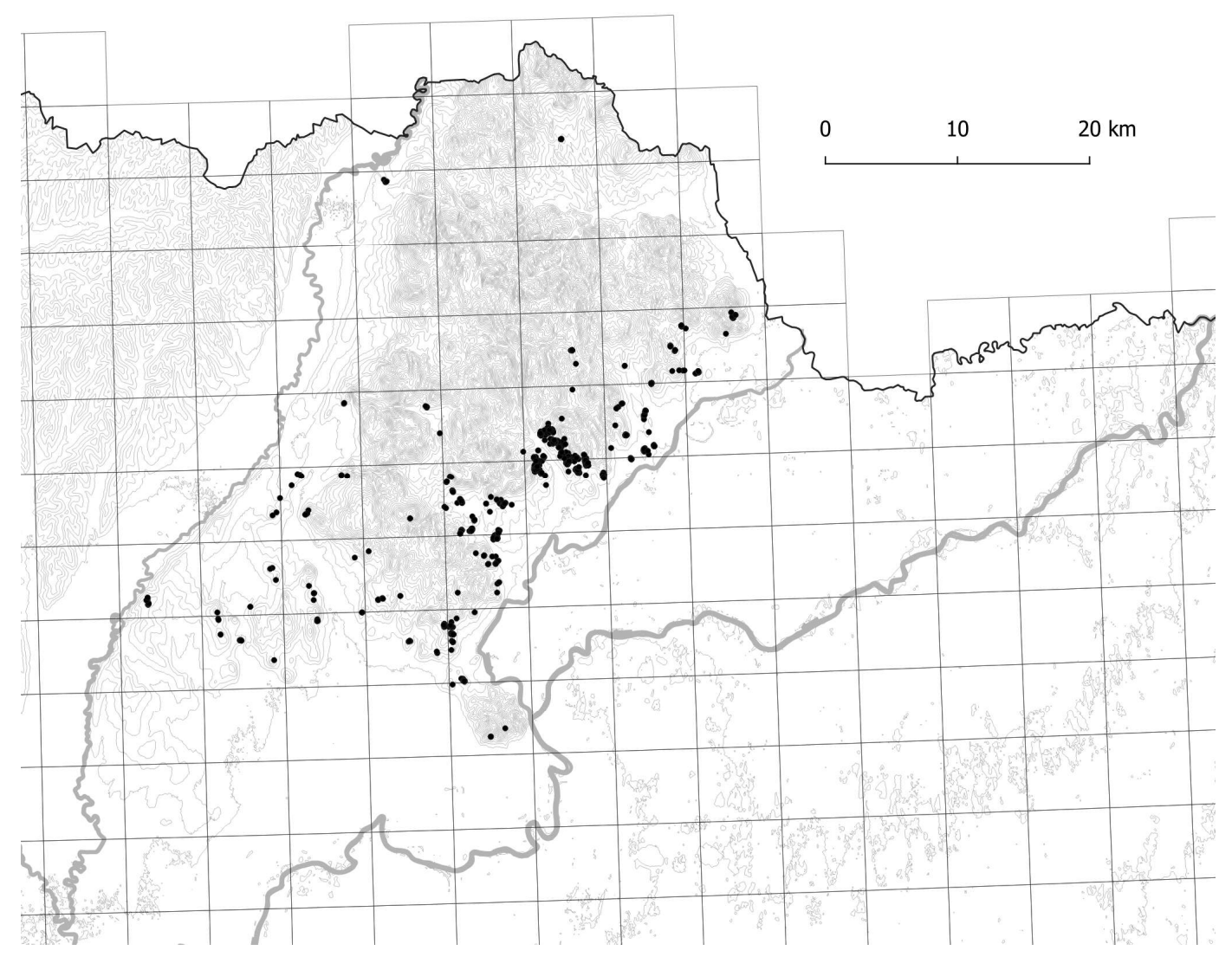

2. ábra A Chamaecytisus albus elterjedése a vizsgált területen

Fig. 2 Distribution of Chamaecytisus albus on the study area

Cephalanthera longifolia (Huds.) Fritsch - A hegyvidék viszonylag elterjedt faja, a Hegyalján viszont már ritkán fordul elő. Herb.: Soó (1937): Sátoraljaújhely: Magas-hegy (DE-Soó). Lit.: A hegység belsejéből származó adatai régről ismertek (ld. pl. KISS 1939, Soó \& HARGITAI 1940, BORSOS 1959, SIMON 2005b). A Hegyaljáról Sárospatak és Sátoraljaújhely környékéről vannak régebbi adatai (CHYZER 1905, KISS 1939). Adataink egy része a régiek megerősítése, néhány új lelőhellyel kiegészítve. Ined.: Erdőhorváti: Hajagos-oldal, Szelek-fej, Hegyes-hegy gyertyánostölgyesekben [7694.1] (SZZS 2017); Sárospatak: Bancsi-gödör gyertyános-tölgyes eróziós árokban [7695.1] (LL, TP 2011); Sátoraljaújhely: Hosszú-domb [7595.4] (SZZS, TP 2015), Kecske-hát, Magas-hegy gyertyános-tölgyesekben [7695.2] (SZZS 2016); Bodrogolaszi: Bodóhegy szőlőparlagon kialakult erdősödő lejtősztyeppben [7794.2] (TIJ 2018).

Chamaecytisus albus (Hacq.) Rothm. - Gyakori védett faj a Hegyalján (2. ábra). Nem különösebben érzékeny, mezsgyékben, parlagok szélén is előfordul, ha van a közelben propagulumforrás, akkor korán betelepül a felhagyott parcellákba. Herb.: Hulják (1912): Abaújszántó, (1924): Tolcsva; Hargitai (1938): Sárospatak; Soó (1938): Boldogkőváralja. Lit.: CHYZER (1905): Tolcsva; KISS (1939) a Hegyaljáról több helyről közli; Soó \& HARGiTaI (1940): Sárospatak. Újabban MOLNÁR \& TÜRKE (2007), MOLNÁR et al. (2016). Ined.: részben KISS (1939) adatainak megerősítése: Sátoraljaújhely: Bessenyei-oldal, Szár-hegy-alja, Boda-dúlő [7695.2] (TIJ, FB, BA 2015); Hercegkút: Gombos-hegy, Fürdő-dűlő [7695.3] (TMO 2014); 
Komlóska: Mogyorós-tető [7694.2] (DA 2014); Olaszliszka: Csontos, Sajgó; Erdőbénye: Messzelátó, Nagy-ösztvér, Eresztvény, Lapos-Mogyorós [7794.1] (TMO 2014), Felső-liget [7793.2] (TIJ 2018); Baskó: Hallgató-tető [7693.4] (SJ 2012); Rátka: Kerek-tölgyes, Éj-hegy [7793.4] (TMO 2014); Olaszliszka: Sajgó [7794.3] (TMO 2014); Bodrogkeresztúr: Henyedomb [7894.3] (ZST, FB 2016); Gönc: Rózsás-tető [7593.2] (TIJ 2016); Füzérkomlós: Körtvéllyes [7494.4] (LL 2010). Szőlőparlagokon, lejtősztyeppekben.

Clematis alpina (L.) Mill. - Lit.: HuLJÁK (1997): Hollóháza felett a Hosszúbérc oldalában találta meg a Zempléni-hegység magyar oldalán először. A hegység szlovákiai részén ismert (FuTÁK 1982), jelzett előfordulási helye légvonalban kb. 45 km-re északra található a Hoszszúbérctől. Azóta újabb helyről nem közölték. Ined.: Nyíri: Vörösvíz-oldal, egykori bányászgödrök szélén, bükkösben (SZZS 2011).

Cnidium dubium (Schkuhr) Thell. - A Bodrogköz mocsárrétjeire jellemző faj felkúszik a Hegyalja alacsonyabban fekvő üde gyepjeire is. Lit.: A Hegyaljáról egyedül KIss (1939) említi Olaszliszkáról, de nem derül ki, hogy az ártéri rétekről van-e ez az adata, vagy a hegylábi részről. Ined.: Előkerült Erdőbényéről a Messzelátó alján levő vizenyős rétről [7794.1] (TIJ 2017), és Sima közeléből, a Mocsilda-völgy patak menti kaszálórétjéről [7693.4] (TIJ 2017) is.

Dactylorhiza sambucina (L.) Soó - A Hegyaljára új! Herb.: Legközelebb: Simon (1955): Telkibánya: Bohó-rét (BPU). Lit.: HAZSLINSZKY (1864) említi Abaúj Vármegye hegyi rétjeiről. A Zempléni-hegységből a Bohó-rétről és környékéről (SIMON 1977, 2005b, MoLNÁR V. 2011) valamint Telkibánya: Hemzső-rétről (MATus et al. 2019) van recens adata. Ined.: Komlóska: Matisz-domb erősen erdősödő lejtő- és erdőssztyepp mozaikból [7694.4] (LL 2017).

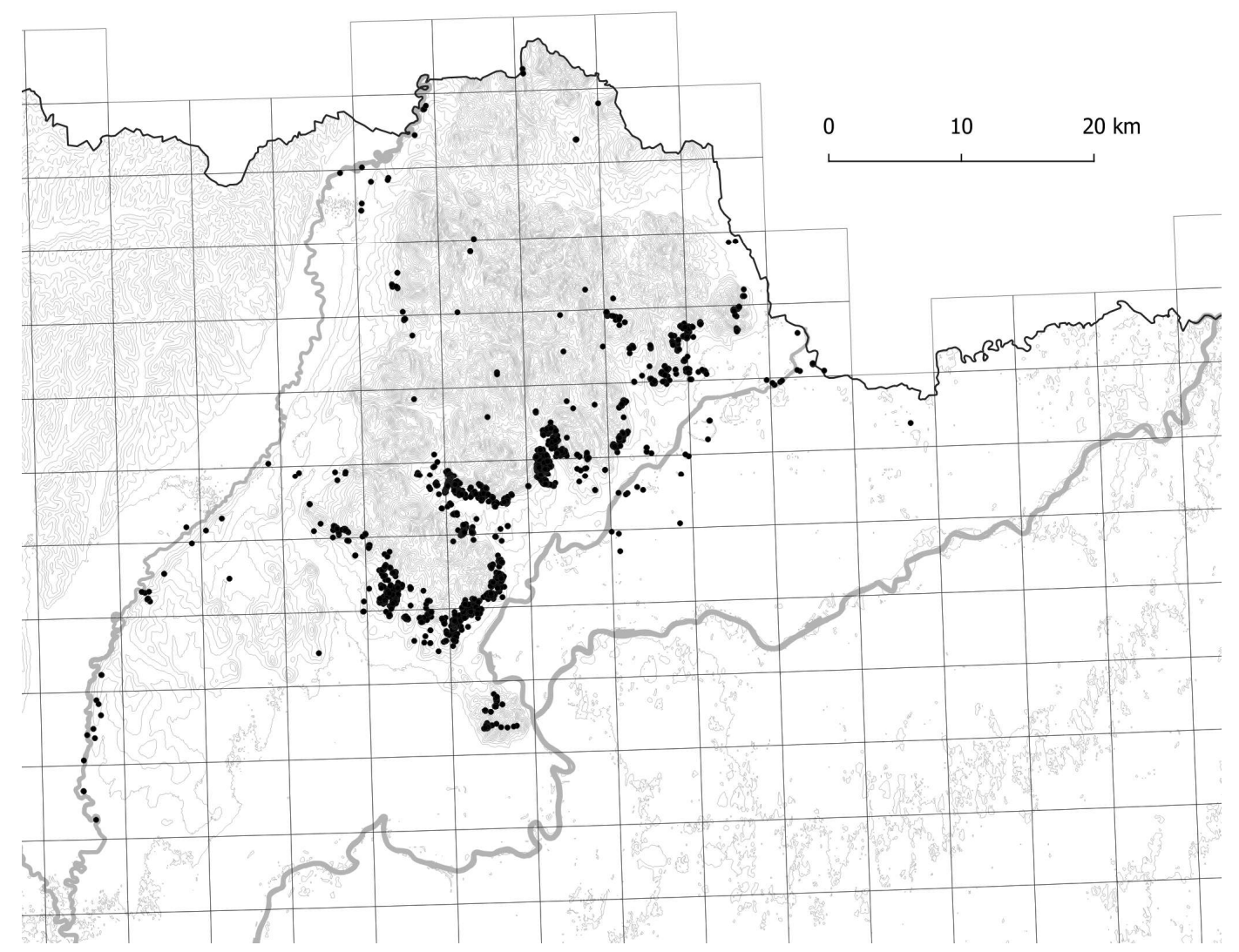

3. ábra A Dianthus collinus elterjedése a vizsgált területen

Fig. 3 Distribution of Dianthus collinus on the study area 
Dianthus collinus Waldst. et Kit. - Lit.: Már KISS (1939) és MoLNÁR \& TÜRKE (2007) is jelzi, hogy kimondottan gyakori a Hegyalján (ld. továbbá MolnÁr et al. 2016, MATUS et al. 2019, FARKAS 2010). A részletes feltáró munkánknak köszönhetően tájegységünkben teljesebb képet kaptunk e faj elterjedési viszonyairól is (3. ábra). Ined.: Tállya: Galyagos, Palota-hegy [7793.3], Vár-hegy, Fördős-tető, Vány-hegy; Mád: Sarkad-hegy, Ősz-hegy alja [7793.4] (TMO 2014); Felsődobsza: Uraság-dűlője [7792.2] (KJ 2013); Erdőbénye: Felső-liget, Becsk; Sima: Csonkás [7793.2], Alsó-csörgő [7693.4] (TIJ 2017); Tolcsva: Meleg-máj, Gyopáros, Bartalos [7794.2] (TMO 2014); Erdőhorváti: Hajagos-oldal [7694.1] (FB 2014); Hejce: Ligetek [7593.4] (TIJ 2017); Sátoraljaújhely: Nagy-Cepre, Tompa-dűlő [7595.4] (TIJ, FB, BA 2015); Gönc: Róka-dűlő, Rózsás-tető, Haraszka [7593.2] (TIJ 2016). További adat: Füzér: Oldal-föld [7494.4] (LL 2011). Parlagokon, lejtőgyepekben.

Dryopteris carthusiana (Vill.) H. P. Fuchs - A Zempléni-hegység középső és északi részein gyakori faj (ld. pl. SimON 2005a,b), a Hegyaljáról azonban kevés adata ismert, az alábbiakban ezen terület régi és új adatait közöljük. Herb.: Simon \& Jakucs (1949): Sárospatak (DE-Soó). Lit.: KISS (1939) még csak néhány helyről említi: Erdőbénye: Sás-patak, Erdőhorváti: Kis-Tolcsva-patak. Újabban is csupán szórványos adatait közölték a térségből (MARSCHALl \& TUBA 2009, MolNÁR et al. 2016, 2018). Tapasztalataink szerint szinte minden hűvösebb patakvölgyben megtalálható. Ined.: Erdőbénye környékéről több helyről is előkerült: Aranyosi-völgy (SuJ 1996, 2003), Alsó-liget [7793.2], Tábori-tag patakok mentén, Sötétes alja sziklahasadékban, Bényei-patak mentén több helyen [7794.3], Kis-erdő égeresében [7794.1] (TIJ 2018, HTIJ); Tállya: Kopasz-hegy, vízszivárgásos, tőzegmohás helyen több tő [7793.4] (TIJ 2018); Makkoshotyka: Nagy-mély-völgy, patak mentén [7695.1] (TIJ 2018, HTIJ).

Dryopteris dilatata (Hoffm.) A. Gray - Az egész Zempléni-hegységből kevés adata van. Lit.: FARKAS (1999), MolNÁR et al. (2016), CSIKY et al. (2018). A Hegyaljáról MARSCHALL \& TuBA (2009) közli Sárospatak Király-hegyről (ezt az adatot mi is megerősítettük). Mád környékéről flóratérképezési adata ismert (Szalóky I., [1]). Tapasztalataink szerint a D. carthusiananál jóval ritkább, de sokszor vele együtt fordul elő és a hegység északi részein kívül a Hegyalja hűvösebb patakvölgyeiben is gyakran megtalálható. Ined.: Tokaj: Tarmag-kőbánya [7894.3] (ZST 2007); Erdőbénye: Zelenád-gödöri-tag [7794.3], Kis-erdő [7794.1] (TIJ 2018, HTIJ); Abaújszántó: Aranyos-völgy [7793.2] (TIJ 2018); Erdőhorváti: Haraszt-tisztás [7694.3] (TIJ 2018, HTIJ); Sárospatak: Király-hegy [7695.3] (DA 2014). További adatok a hegység belsejéből: Regéc: Csaponta-forrási tag [7594.3]; Kovácsvágás: Négy-Szappan [7595.3]; Kishuta: Szőlőske [7594.2] (SZZS 2016).

Dryopteris expansa (C. Presl) Fraser-Jenk. - Az előző két fajnál sokkal ritkább. Herb.: Simon (2007): Hollóháza (BPU). Lit.: FARKAS (1999) már említi a Zempléni-hegységből, MoLNÁR et. al. (2016): Komlóska; Kevey (2015): Fony; CsIKY et al. (2018): Telkibánya. A Hegyaljáról eddig csak Mád környékéről volt flóratérképezési adata (Szalóky I, [1]). Ined.: Tállya: Kopasz-hegy vízszivárgásos, tőzegmohás helyen [7793.4] (TIJ 2016, HTIJ); Sárospatak: Királyhegy [7695.3] (DA 2014); Erdőbénye: Zelenád-gödöri-tag patak menti égeresben [7794.1] (TIJ 2018, HTIJ). További adat a hegység belsejéből: Pálháza: Kemence-patak-völgye [7594.2] (DA 2014).

Echium maculatum L. - Számos herbáriumi és irodalmi adatát ismerjük a hegységből. Lit.: A legtöbb irodalmi adat a Hegyaljáról származik (ld. pl. HAZSLISZKY 1866, CHYZER 1905, JÁvORKa 1935, KisS 1939, HARGitai 1940, Simon 2005a, MolnÁR \& TÜRKE 2007, FARKAS 2010, FARKAS 2011). Ined.: Komlóska: Matisz-domb [7694.4] (LL, TP 2011); Bodrogolaszi: Lencsés-dűlő, Somos-szőlő [7795.1] (LL 2014); Sárospatak: Kis-hegy [7695.3] (LL 2011); Bekecs: Csillag [7892.4] (PZ 2012); Monok: Pipske [7892.2] (PZ, ZST 2011); Nagyhuta: Kékszűrő [7695.1] (PG 2009); Fony: Dabróka-tag [7693.2] (SJ, BI 2012); Arka: Tó-hegy [7693.3] (SJ 2016); Baskó: Akasztó-domb [7693.4] (BI 2011). Jó állapotú lejtőgyepekben. 
Epilobium palustre L. - A Zempléni-hegységben nagyon ritka. Herb.: Soó (1939): Pálháza (DE-Soó). Innen azóta nem került elő. Lit.: Eddig csak a Bohó-rétről volt recens adata (MATUS et al. 1993) és a hegység szlovákiai részéről ismert néhány előfordulása (BERTovÁ 1988). Ined.: Nagyhuta: Komlóska-völgy, lápréten, Thelypteris palustris-ok társaságában. Soó Rezső vélhetőleg a közelből gyűjtötte [7594.4] (TIJ 2017).

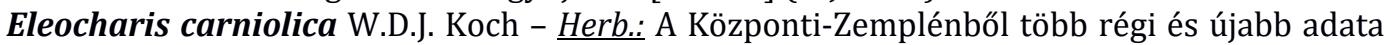
is ismert. Jávoka (1951): Kemence-patak-völgye; Csapody (1953, 1955): Kőkapu; Boros (1954): Kishuta: Lackó-hegy, Bózsva: Senyő-völgy (BP). Hulják (1940): Kemence-patak; Matus \& Molnár (2002): Regéc: Bohó-rét; Matus \& Takács (2011): Telkibánya (DE-Soó). Siroki (1967): Háromhuta: Nagy-bekecs (DE-Siroki). Lit.: SiMON (2005a) 1954-ben Középhuta mellett a Kemence-patak mellől közli. FARKAS (1999): Kőkapu, Gyertyánkúti-rétek. Ined.: Regéc: Bekecs-oldal [7594.3] (PG 2010). Siroki Zoltán valószínűleg a közelből gyűjthette.

Epipactis albensis Nováková \& Rydlo - Lit.: Molnár V. Attila közli a füzéri Vár-hegyről (MolnÁr V. et al. 2000), továbbá FARKAS (2010) jelzi Hernádszentandrásnál nemesnyarasokból. Ined.: Mogyoróska: Kert-alja-erdő, a regéci vár parkolója melletti gyertyánostölgyesben [7694.1] (HaA 2017).

Epipactis atrorubens (Hoffm.) Besser - Lit.: Hulják János adatait Kiss közli (1939): Hejce: Fonyi erdő, Óhuta: Huta-völgy-patak; Soó \& HARGiTAI (1940): Hercegkút: Darnó. Újabban Vojtkó András Füzér környékén találta meg (2004 [1]), FARKAS (2011): Erdőhorváti: Puszta-várról és a Szár-hegyről közli. Ined.: Füzér: Kelemen-bérc, bükkösben [7494.2] (LL 2008).

Epipactis exilis P. Delforge - Lit.: Hazánkban csak a Kőszegi-hegységből és a Zemplénihegységből ismert faj. PELLEs (1997) a mikóházi Málnás-völgyből közli, és jelzi, hogy a faj várhatóan máshonnan is előkerül. Ined.: 2018-ban Erdőbénye Felső-Ligetről került elő igen hasonló élőhelyről, mint a mikóházi: bükkös erdő mély völgyében, patak mellett két tő [7793.2] (TIJ 2018). A határozásban segítettek Makádi Sándor (Budapest) és Molnár V. Attila (Debrecen).

Epipactis nordeniorum Robatsch - A Zempléni-hegységre új! Lit.: Legközelebbi adata a Börzsönyből származik (MolNÁR V. 2011). Ined.: Háromhuta: Huta-völgy (PG 2010) [7694.1]; Erdőbénye Felső-Liget, Bényei-patak mentén néhány 10 tő [7793.2] (TIJ 2018). A faj határozásában segítségünkre volt Molnár V. Attila (Debrecen).

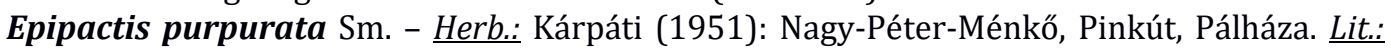
Adatainak többsége a Zempléni-hegység középső és északi részéről származik: KISS (1939): Füzér: Vár-hegy, Háromhuta: Szurok-hegy, Regéc: Vár-hegy. A hegyaljáról csak Erdőbénye mellől volt ismert: FARKAS (2011): Erdőbénye: Szokolya. Ined.: Gyertyános-tölgyes és bükkös állományokból került elő. Kéked: Szurok-hegy [7494.1] (SZZS 2017); Pányok: Ökörhegy [7494.3] (SZZS 2013); Füzér: Hajagos [7494.2] (SZZS 2016); Gönc: Új-hegy [7593.2] (SZZS 2017); Fony: Kőszáli-erdő; Bagoly-kő [7593.4] (TIJ 2017); Regéc: Lapuhas [7594.3] (LL 2010); Nagyhuta: Nagy-Som-hegy [7595.3], Lengyel-vályú-forrási tag [7695.1]; Mogyoróska: Farkas-verem, Tölgyes-tető [7694.1] (SZZS 2017). Újabb adat a Hegyaljáról: Erdőhorváti: Kerekded [7694.3] (TIJ 2019).

Equisetum hyemale L. - Herb.: Simon Tiborné (1955): Makkoshotyka felett, ill. Középhuta, patak mellett (DE-Siroki). Lit.: MARGITTAI (1933): Kishuta: Kemence-patak-völgy. KiSS (1939) Középhutából említi a Nagy-Tolcsva-patak mellől. Simon Tibor 1961-ben Telkibányán a Nagy-patak-völgyben találja meg (SIMON 2005b). Ined.: Hollóháza: Belterület [7494.4] (LL 2009); Nagyhuta: Felső-határ-völgy [7594.4] (TIJ 2018); Erdőhorváti: Hegyeshegy [7694.1] (LL, TP 2011); Sárospatak: Radvány-völgy [7695.1] (PG 2008). Patakparti égeresekben. 
Erysimum witmannii subsp. pallidiflorum (Jáv.) Jáv. - A taxon típusterülete a váci Naszály és a Börzsöny (JÁVORKA 1912). Később a Zempléni-hegységből is előkerült (lásd alább Hulják J. és Margittai A. adatait), majd SIMON (1992) határozója forrásmegjelölés nélkül jelezte még a Bükkből és a Tarnavidékről. Az utóbbi területekről és a Zempléni-hegységből azóta nem erősítették meg a jelenlétét. BARINA (2009) még említi a Bükkből és a Zemplénihegységből, végül BARTHA et al. (2015) térképén csupán a naszályi és börzsönyi előfordulásai jelennek meg, míg a zempléniek (az erősen kérdéses bükki és tarnavidéki adatokhoz hasonlóan) elmaradtak. A közelből még a Gömör-Tornai karsztról ismert (MichALKOVÁ 1999, VIRÓK et al. 2016). Zempléni előfordulását ezúton erősítjük meg. Herb.: Hulják (1938): Arka, (1940): Erdőbénye (BP). Lit.: HULJÁK (1926): Tállya, (1938): Boldogkőváralja; MARGITTAi (1938): Bodogkőváralja; SiMON et al. (2007): Tállya környéki száraz rét. Ined.: Erdőbénye: Szokolya-oldal [7793.2] (PG 2010); Arka, Boldogkőváralja: Tó-hegy több száz tő [7693.3] (PG 2010). Kőtörmelékes hegyoldalakon.

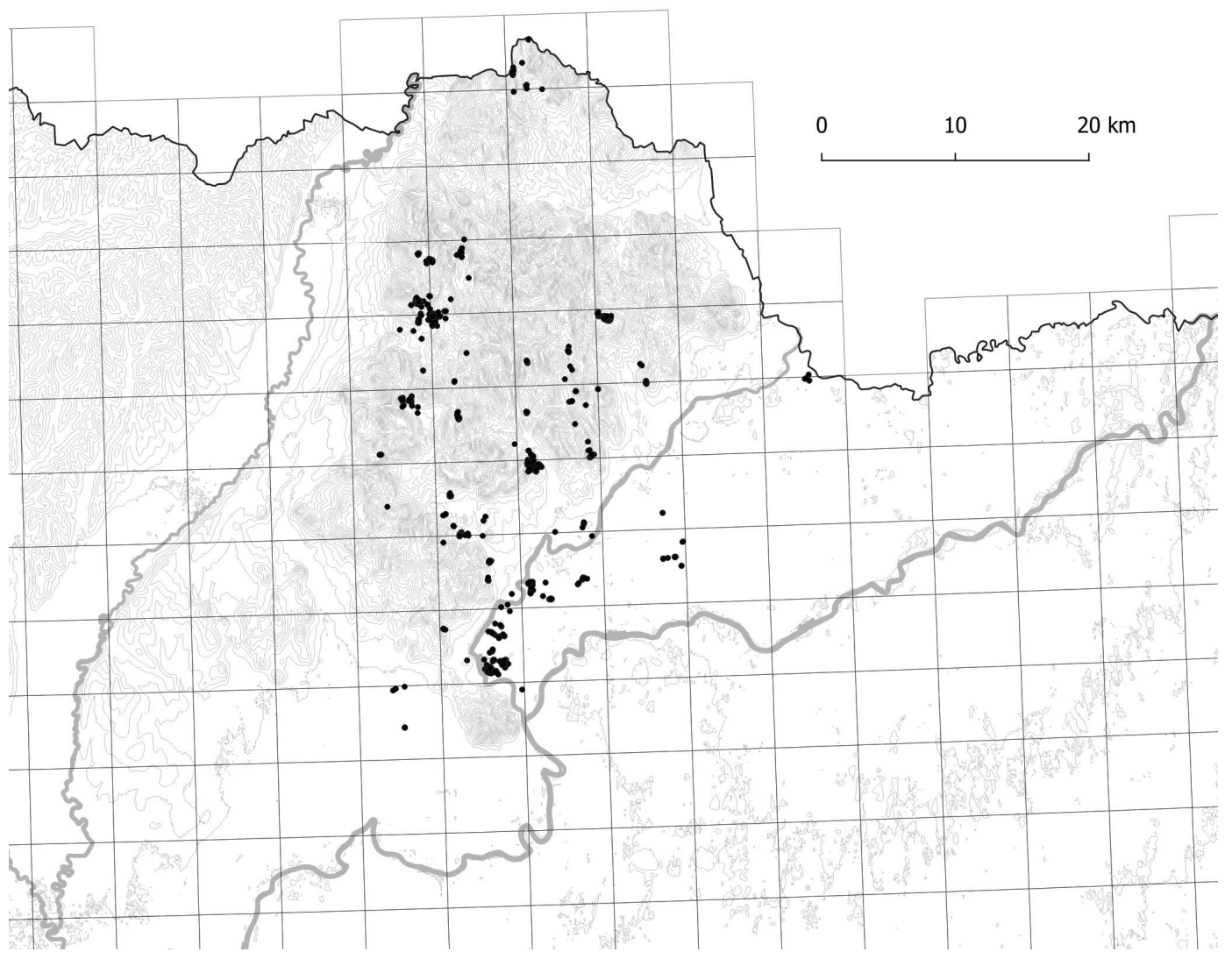

4. ábra A Gentiana pneumonanthe elterjedése a vizsgált területen

Fig. 4 Distribution of Gentiana pneumonanthe on the study area

Gentiana pneumonanthe L. - A Zempléni-hegység üde hegyi rétjeiről régóta ismert (pl. KISS 1939, Simon 2005a,b, FARKAS 2011, MolnÁR et al. 2016, 2019). A Hegyalján már ritkábban fordul elő. Korábbi adatait innen részletezzük. Herb.: Hulják (1939): Tállya: Murány; Jakucs (1950): Erdőbénye: Vár-hegy (DE-Soó). Lit.: KISS (1939): Mád, Tállya. Újabban MoLNÁR \& TÜRKE (2007) közöl adatokat innen. Ined.: Erdőbénye határából több új helyről is előkerült: Hecske plató helyzetű pangóvizes árokban (TIJ 2016), Messzelátó alja völgyalji vizes élőhelyen (TIJ 2017), Kis-Ösztvér üde rétről (TIJ 2015). További adatai hegyi rétekről, 
regenerálódó parlagokról: Abaújalpár: Urbános-rét [7693.4] (SJ 2013); Tállya: Villongó [7793.2] (SJ 2017); Tolcsva: Gyopáros, Bartalos; Erdőhorváti: Meleg-máj [7794.2], Rigócska [7694.4] (TMO 2014), Közép-bérc, Kopaszka [7694.2] (LL, TP 2011); Sárospatak: Királyhegy, Fürdő-dúlő [7695.3] (TMO 2014); Olaszliszka: Nagy-Meszes [7794.3] (TMO 2014). További adatok a hegység belsejéből: Füzér: Magas-tető, Mik-rét [7494.4] (SZZS, TP 2012), Drahosi-rét [7494.2] (LL 2008); Nagyhuta: Kékszűrő [7695.1] (LL, TP 2011); Regéc: Kovács-domb-alja [7694.1] (SJ 2010); Fony: Nagy-Mocsolya, Egresek-dúlő [7693.2] (SJ 2012).

Geum rivale L. - Lit.: Magyarországon eddig csak a Putnoki-dombságból észlelték a fajt (PENKSZA \& SomLYAY 1999). A Zempléni-hegység északi részén is meglehetősen ritka fajt (BERTOVÁ 1992) a hegység magyarországi részén először 2003-ban Mogyoróska mellett Nagy Gábor és Hegedűs Attila találta meg (NAGY 2011). Ined.: Adatunk Nagy Gáborék adatának pontosítása. Mogyoróska: Baskói-rét, Farkas-domb [7694.1] (ZST, SZA 2012). Égerliget szélén ezres nagyságrendủ állomány.

Gladiolus imbricatus L. - Herb.: A hegység belsejéből több helyről ismert: Egey (1931): Komlóska (BP); Hulják (1937): Regéc (DE-Soó), Mogyoróska, (BP), (1938): Telkibánya (DESoó), Fony (BP); Schudich (1938): Füzér; Boros (1949): Pálháza; Vajda (1954): Bózsva; Siroki (1961): Háromhuta (DE-Siroki); míg a Hegyaljáról csupán kevés régi adata származik: Bánó (1948) Tállya: Dorgó-tető (BP); Vida (1953): Erdőbénye (EGR). Lit.: A hegység belsejéből KISS (1939), Soó (1940), HARGiTAI (1944), Simon (2005a,b, 2007) közölnek adatokat, újabban PATALENSZKY (2012): Baskón, MATus et al. (2019) Telkibányán találja meg. A Hegyaljáról KIss (1939) írja a sárospataki Radvány-rétről, és Tállyáról (Erdőbénye) a Szokolya-hegyről. Ined.: Több hegyi rétről és láprétről is előkerült. Telkibánya: Csepegő-kútitag [7594.1] (SZZS 2008); Regéc: Kovács-domb-alja [7694.1] (LL, TP 2012); Baskó: Magyarrét [7693.4] (ZST 2009), Bika-rét [7694.3] (BI, SJ 2011), továbbá előkerült Mád községhatárából a Pipiske-kúti tagból dózerút mentén levő erősen cserjésedő hegyi rétről [7793.4] (SJ 2018).

Gymnadenia conopsea (L.) R. Br. - A Központi-Zemplénben több helyről ismert (KISS 1939, Simon 1977, Matus et al. 1993), a hegység déli részén már sokkal ritkább alább erről a területről részletezzük az adatokat. Herb.: Soó (1947): Tokaj: Nagy-Kopasz (DE-Soó). Lit.: KISS (1939): Abaújszántó: Aranyosi-völgy, Erdőbénye: Szokolya, Erdőbényefürdő: Bogán-hegy, Erdőhorváti: Kis-Tolcsva-patak, MATus et al. (2019): Telkibánya. Ined.: Tállya: Fürdős-oldal; Mád: Kúkja-tető [7793.4] (TIJ, FB, ZST 2014); Baskó: Magyar-rét [7693.4] (SJ 2017), Bikarét [7694.3] (HA 2017).

Gymnocarpium dryopteris (L.) Newman - A Zempléni-hegység északi részén gyakori faj (ld. pl. KISS 1939, JÁVORKA 1935, SimON 2005a, CSIKY et al. 2018, MATUS et al. 2019) a Hegyalján jelentősen megritkul. Alább ezen terület adatait részletezzük. Herb.: Boros (1952): Erdőbénye; Soó (1948): Erdőbénye (DE-Soó). Lit.: KISS (1939): Erdőbényefürdő: Bogdán-hegy, Erdőhorváti: Kis-Tolcsva-patak; Soó \& HARGiTaI (1940): Károlyfalva: Somlyód. Újabban MolNÁR et al. (2016): Erdőhorváti: Cseke-kő. Ined.: Erdőbénye: Felső-Liget patak mentén [7793.2] (TIJ 2018). További új adatok a hegység északi részéről: Mogyoróska: Három-hegy [7693.2] (BI, DA 2014); Regéc: Csenkő-patak-völgye [7594.3] (LL 2013); Füzér: Bogdányhegy, Fagyos-forrás völgyfő [7494.4] (BS 2017).

Inula germanica L. - A hegyvidék déli, löszös területeiről voltak eddig adatai Herb.: Siroki (1943): Abaújszántó szőlőhegyen; Soó (1947): Tokaj: Nagy-Kopasz (DE-Soó). Lit.: HAZSLISZKY (1866): Tokaji-hegy, Hegyalja; KIsS (1939): Abaújszántó, Boldogkőváralja, Tokaj, Tállya, Hejce; SIMON $(2005 a, b)$ : Tokaj. Újabban Molnár \& TÜRKE (2007) és MolnÁR et al. (2016) közöltek adatokat. Most többek között a Hegyalja északibb részéről is előkerült. Ined.: Abaújszántó: Kassi-szőlő [7793.1] (2014 TMO); Legyesbénye: Fuló-hegy [7892.2] (TIJ, FB 2015); Tállya: Nyerges-hegy [7793.4] (TIJ, FB 2015); Sárospatak: Szemince-hegy [7695.3] (TIJ 2015). Szőlőparlagokról, sztyepprétekről. 
Inula helenium L. - Herb.: Simon (1951): Regéc: Hutai-patak (BPU). Lit.: Szerencs környékéről már Kitaibel említi (Gombocz 1939), Boros (1970) Vajda László adatát közli Kékedről. Eddig nem volt recens adata a térségből, annak ellenére, hogy a környékről az Aggtelekikarsztról, a Cserehátból és a Putnoki-dombságból is több adata van (pl. VIRóK et al. 2004, VојтKó 2008). Ined.: Erdőbénye környékéről került elő közút mellől [7794.3] (SuJ 2005). Azóta évekig nem találtuk, mert az út szélét rendszeresen lekaszálták, 2018-ban azonban az elmaradt kaszálás miatt termést is tudott itt érlelni (TIJ 2018). Pányokról is előkerült a Vízmű-tagból, a falu temetőjétől nem messze [7494.3] (SZZS 2019).

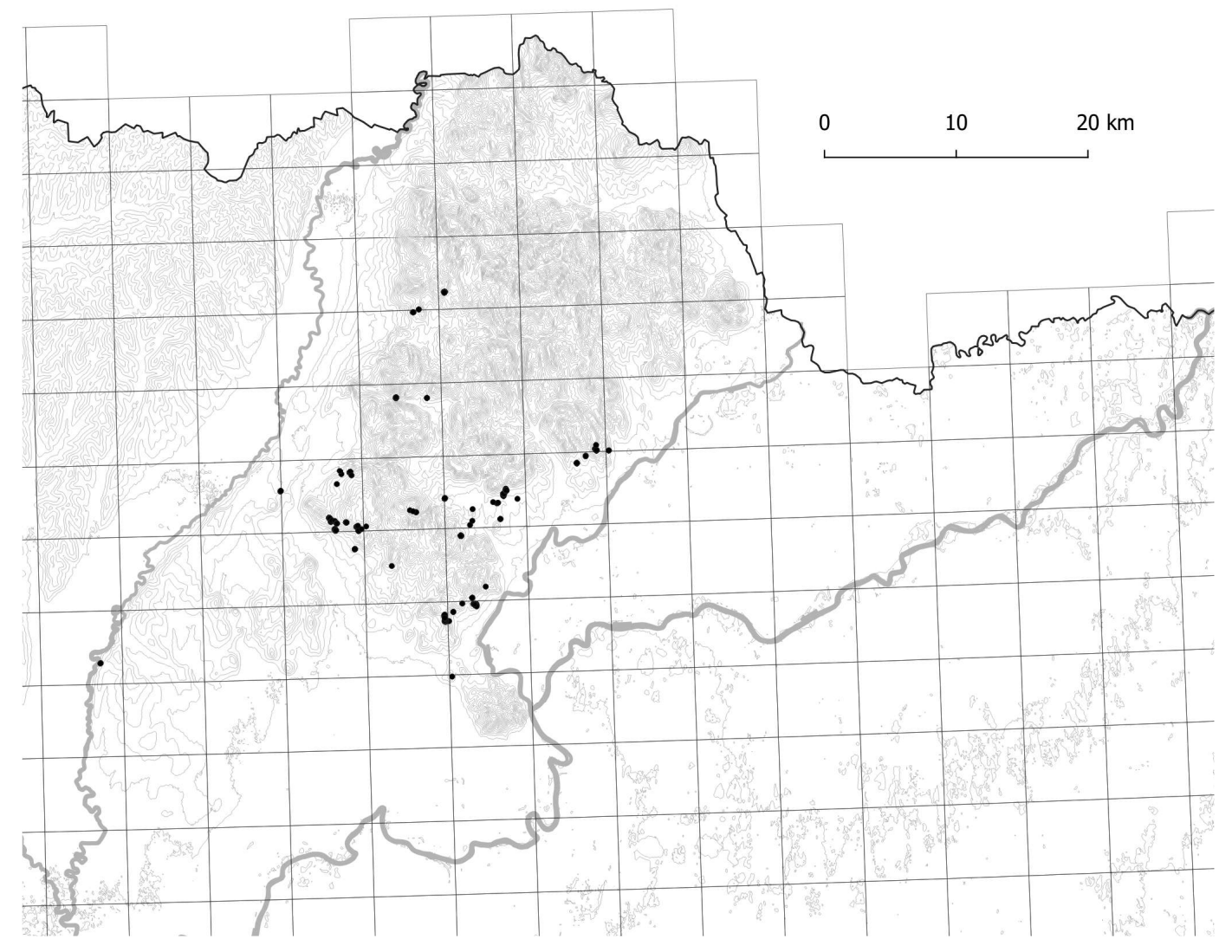

5. ábra Az Iris aphylla subsp. hungarica elterjedése a vizsgált területen

Fig. 5 Distribution of Iris aphylla subsp. hungarica on the study area

Iris aphylla subsp. hungarica (Waldst. et Kit.) Hegi - Herb.: Hulják (1940): Erdőbénye Várhegy; Jávorka (1936): Tállya (DE-Soó). Lit:: Már Kitaibel is említi Monokról (GomBocz 1939), HAZSLINSZKY (1864) és KISS (1939) a Hegyaljáról több adatot közöl. BoRos (1930) Tokajról, Soó \& HARGITAI (1940) Abaújszántóról és Boldogkőváraljáról, az utóbbi településről HULJÁK (1938) is írja. LAKATOS (1975): Peréről, Felsődobszáról, Újcsalánosról, SIMON (2005a): Peréről írja. Újabban MARSCHALL (2004) Erdőbénye; MolNÁR \& TÜRKE (2007): Monok, ahonnan azóta valószínűleg eltűnt (Molnár Cs. ex verb.); FARKAS (2011): Abaújszántó, Erdőbénye, Olaszliszka. Ined.: A Hegyalján nem ritka lejtőszeppekben, erdőszéleken, akár mezsgyékben is előfordul. Több új helyről is előkerült, ezek közül a fontosabbakat emeljük ki: Bodrogkeresztúr: Messzelátó [7894.1] (TIJ 2015); Olaszliszka: Galagonyás (TIJ 2016); Erdőbénye: Becsk-tető [7794.1] (SJ 2014), Szokolya-oldal [7793.2] (PG 2004); Fony: Kis-Szárkő [7693.2] (FR 2010); Komlóska: Matisz-domb [7694.4] (LL 
2017); Sárazsadány: Szár-hegy [7794.2] (LL 2011); Bodrogolaszi: Lencsés-dűlő [7795.1] (LL 2017); Tállya: Palota-hegy [7793.3], Rohos [7793.1] (SuJ 2005); Boldogkőváralja: Polánkai-tag [7693.4] (SuJ 2005); Tarcal: Kereszt-hegy, Terézia-domb [7894.3] (ZST 2005). Két talán legérdekesebb adata: Sóstófalva: Hoporty a Hernád szakadópartján [7891.2] (PZ 2012), és előkerült Regéc Nagy-Szárkőről [7594.3] (FR 2010) is, ami az eddig ismert legészakibb előfordulása a Zempléni-hegységből.

Iris graminea L. - Lit.: Szórványos adatai vannak a környékről. Elsőként Kitaibel (GoMBOCZ 1939) említi Tállya (Erdőbénye) Szokolya-hegyről, ahonnan recens adata is van (FARKAS 2011). KIsS (1939): Monok: Kővágó-tető, Sárospatak: Radvány-rét, Szerencs: Hideg-völgy; Soó (1938): Füzéri vár; Soó \& HARGITAI (1940): Iris graminea subsp. pseudocyperus „Tállya felett, Abaújszántó felé". A fenti adatok nagy része azóta nem került megerősítésre. Újabban MolnÁR et al. (2016) Fonyról jelzi több helyről. Ined.: Baskó: Akasztó-domb [7693.4] (SJ 2017); Fony: Tekenős-alja [7693.2] (SJ 2016); Regéc: Dabróka-dűlő [7694.1] (SJ 2016); Szentistvánbaksa: Magas-part (Bika-rét) néhány tő erdősszyteppréten [7792.3] (BS 2010). A Hernád-mentéről régebben egyáltalán nem volt adata.

Iris sibirica L. - Lit.: A hegységből több helyről ismert (pl. KISS 1939, Matus 1997, SimoN 2005b), újabban MolnáR et al. (2016): Regéc; PATALENSZKY (2012): Baskó: Bika-rét, Pásztor rét, Erdőbénye: Nagy-Mondoha; TAKÁcs et al. (2016): Erdőbénye: Alsó-rétek (az EOTR térképszelvény alapján helyesen: Nagy-rétek - Takács A. in litt.). Ined.: A Zemplén déli részén ritkának számít. Erdőbénye: Messzelátó [7794.1] (TIJ 2017); Sima: Alsó-csörgő [7793.2] (TIJ 2017); Sátoraljaújhely: Fogarasi-rét [7695.2] (LL, TP 2011) mocsárrétekről. További adatok a hegység központi részéből: Pusztafalu: Rigó degradált üde gyep mélyedésében [7495.1] (SZZS, TP 2013); Füzér: Németki-dűlő üde hegyi réten [7494.4] (LL, TP 2012); Felsőregmec: Dobonya láprét maradványfolton [7495.4] (LL 2009); Baskó: Akasztó-domb [7693.4] (SJ 2012); Erdőhorváti: Hegyes-halom [7694.4] (LL 2017).

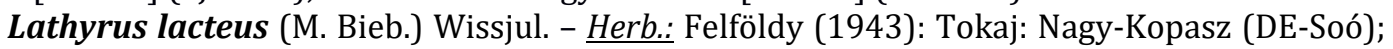
Simon (1962): Tolcsva (BPU). Lit.: HAZSLISZKY (1866): Hegyalja; SIMON (2005b): Szerencs: Aranka-tető. Újabban MolNÁR \& TÜRKE (2007): Szentistvánbaksa, Tállya; TAKÁCS et al. (2016): Tarcal: Kiskopasz; MoLNÁR et al. (2016): Boldogkőújfalu. Ined.: Bodrogkeresztúr: Lapis-oldal [7894.1] (TIJ 2017); Mád: Becsek [7893.2] (TIJ, FB 2015); Erdőhorváti: Véghegy [7694.4] (LL 2011); Bodrogolaszi: Bihajka [7794.2] (TIJ, FB 2015), Lencsés-dúlő [7795.1] (LL 2016); Sárospatak: Szemince-hegy [7695.3] (LL, TP 2011), természetesebb lejtőszeppekben.

Lathyrus nissolia L. - Herb.: Takács (2013): Tokaj (DE-Soó). Lit.: A Hegyalján nem ritka. HAZSLINSZKY (1866): Hegyalja; CHYZER (1905): Sátoraljaújhely; KISS (1939): Bodrogolaszi, Bodrogkeresztúr, Mád, Sátoraljaújhely, Tolcsva; SIMON (2005a): Komlóska. Újabban MoLNÁR \& TÜRKE (2007), MoLnÁR et al. $(2017,2018)$. Ined.: Bodrogkeresztúr: Kővágó [7894.1] (KJ 2013); Mád: Kővágó [7893.2] (FB 2013); Tállya: Vasút alja [7793.3] (SJ 2017); Tolcsva: Meleg-máj [7794.2] (TIJ 2016); Erdőbénye: Omlás [7794.1] (TIJ 2016); Regéc: Parlag-kőszál [7694.1] (TIJ, DA 2017); Makkoshotyka: Makra-tető [7695.1] (LL 2013); Sátoraljaújhely: Ortás, Felső-rét [7695.2] (LL 2013); Komlóska: Alsó-Pudinka [7694.4] (TIJ 2018). Parlagokon, útszéleken, száraz gyepekben.

Lathyrus sphaericus Retz. - Herb.: Soó (1933): Tokaj: Kopasz-hegy (BPU). Lit.: SIMON (2007) említi a Kopasz-hegyről. Legközelebb az Aggteleki-karsztról van még adata (VIRóK et al. 2015: Komjáti). Tapasztalataink szerint a hasonló élőhelyeken megjelenő L. nissolia-nál ritkább, védelemre érdemes faj. Ined.: Erdőbénye: Becsk [7794.1] (ZST 2011); Bodrogkisfalud: Vár-hegy [7894.1] (ZST, TIJ 2016) idősebb szőlőparlagon.

Limodorum abortivum (L.) Sw. - Lit:: A Zempléni-hegységből eddig csak Regéc (Nagyhuta) környékéről, és a Tokaji-hegyről volt adata (ld. FARKAS 1999, MoLNÁR V. 2011, [1]). Ined.: Erdőhorváti: Kerek-fej, zárt tölgyesben [7694.4] (BS 2014). 
Linum hirsutum L. - Herb.: Hulják (1931): Sátoraljaújhely: Vár-hegy (DE-Soó); Soó (1948): Abaújszántó: Sátor-hegy (BPU); Siroki (1971): Tokaj (DE-Siroki). Lit.: Löszhöz kötődő faj, viszonylag ritka a Hegyalján (KISS 1939, BARTHA et al. 2015). Újabban FARKAS (2011) közöl adatokat: Abaújszántó: Sátor-hegy, Erdőhorváti: Nyugodó. Ined: Abaújszántó: Süvegeshegy löszös lejtőgyepben (TIJ 2016).

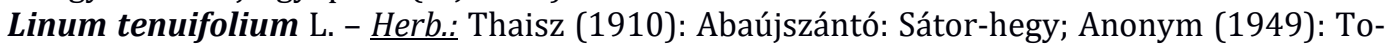
kaj (DE-Soó); Siroki (1971): Tokaj (DE-Siroki). Lit.: HAZSLISZKY (1866), ChYZER (1905): Tokaji-hegy. Újabban MoLnÁR \& TÜRKE (2007) közöl adatokat: Monok: Szőlős-hegy, Szerencs. Ined.: Monok: Őr-hegy lejtősztyeppben [7792.4] (FR 2012); Bodrogkeresztúr: Baktereskőbánya, jellegtelen, kiüresedett lejtőgyepben. [7894.1] (TMO 2014); Tarcal: Terézia-domb [7894.3] (ZST 2005).

Listera ovata (L.) R. Br. - A fajról szórványos adataink állnak rendelkezésre a hegységből. Herb.: Matus \& Takács (2010): Telkibánya, Regéc; Takács (2009): Tokaj (DE-Soó). Lit.: HAZSLINSZKY (1864), ChYZER (1905): Tokaji-hegy; KISS (1939): Óhuta, Regéc; Soó (1940): Tolcsva; SimON (2005b, 1977), NAGY (2011): Mogyoróska: Hármas. Ined.: Bodrogkeresztúr: Henye-domb lejtőgyepben [7894.1] (FB, ZST, SZA 2014); Nagyhuta: Komlóska-völgy [7594.4] (LL 2013); Gönc: Új-hegy erdőszéli tisztáson [7593.2] (SZZS 2017); Füzér: Sarjános-rét erdősödő felhagyott legelőn [7494.4] (SZSZ 2013); Erdőbénye: Csonkási-erdő spontán rezgőnyárral és erdei fenyővel betöltődő irtásterületen [7793.2] (TIJ 2018).

Lycopodium clavatum L. - A hegység középső és északi részein gyakori korpafü dél felé megritkul. Az alábbiakban a hegység déli területről származó adatokat emeljük ki. Herb.: Soó (1948), Borsos (1952): Erdőbénye (DE-Soó); Somlyay (2002): Erdőbénye: Csorgóvölgy, Brónok-völgy, Tállya: Galambos (BP). Lit.: KISS (1939): Sárospatak: Nagy-Száva-hegy; EGEY (1958, In Simon 1992): Sárospatak: Király-hegy, Ciróka; Soó \& Hargitai (1940): Sárospatak: Pusztadélő. Ined.: Erdőbénye: Magyar-rét útrézsűben [7793.2] (SJ 2012); Mád: Bomboly-bánya [7793.4] (ZST 2007). További új adatok a hegység központi részéről: Füzér: Piszkés-tető [7494.4] (PG, SZZS 2011); Pusztafalu: Égések [7495.3] (PG, SZZS 2011); Fony: Meleg-oldal [7593.2] (SZZS 2007); Regéc: Suta-patak-völgye [7594.3] (SZZS 2013); Kovácsvágás: Hercegkúti-patak-völgye [7595.3] (SZZS 2008); Alsóregmec: Devra [7595.4] (SZZS, TP 2013); Fony: Dabróka-tag [7693.2] (BI 2017); Baskó: Sajtház-kert [7694.3] (SJ 2014).

Onosma arenaria Waldst. et Kit. - Herb.: Zsák (1901): Tokaj: Nagy-Kopasz; Jávorka (1936): Sátoraljaújhely: Sátor-hegy; Hulják (1936): Tarcal: Terézia-domb; Soó (1938): Tállya; Siroki (1943): Abaújszántó: Sátor-hegy (DE-Soó); Soó (1947): Tokaj: Kopasz-hegy (BPU); Hulják (1938): Boldogkőváralja (BP). Lit.: HAZSLINSZKY (1866): a tállyai, mádi hegyekről és a Tokaji-hegyről írja. KISS (1939): Abaújszántó, Sátoraljaújhely, Tállya, Tokaj. Újabban MolnÁR \& TÜRKE (2007): Tállya: Rohos. Ined.: Erdőhorváti: Agáros-tető [7694.4] (TIJ 2014); Sárazsadány: Szár-hegy [7794.2] (TIJ 2014); Sátoraljaújhely: Sátor-hegy [7695.2] (TIJ 2014). Minden esetben jobb állapotú lejtősztyeppeken.

Ophioglossum vulgatum L. - Erről a nehezen észrevehető fajról az egész hegységből csak szórványos adatok állnak rendelkezésünkre. Valószínúleg sokkal gyakoribb. Herb.: Matus \& Takács (2015): Regéc: Bohó-rét (DE-Soó). Lit.: Soó \& HARGITAI (1940): Füzérradvány; BoroS (1954): Telkibánya; SIMON $(2005 b, 1977)$ : Regéc. Újabban MolnÁR et al. (2016): Fony. Ined.: Mogyoróska: Hármas [7694.1] (ZST 2012); Háromhuta: Ló-legelő [7694.2] (LL, PG 2011); Tarcal: Terézia-domb ezres nagyságrendű állomány [7894.3] (ZST, FB 2016); Tokaj: Csepegő-dűlő, kaszált gyepen (ZST 2010); Olaszliszka: Kis-Meszes [7794.3] (TIJ 2016); Komlóska: Alsó-Pudinka; Erdőhorváti: Czink-dűlő [7694.4] (TIJ 2018) regenerálódó, erősen cserjésedő szőlőparlagokon és erdőszegélyekben.

Orchis coriophora L. - Herb.: Siroki (1961): Háromhuta: Zsidó-rét (DE-Siroki). Lit.: A hegység belsejéből ismert néhány helyről: Regéc: Nagy-Péter-mennykő (Kiss 1939); Baskó, 
Komlóska (FARKAS 1999). Recens adata nem volt a Hegyaljáról, bár már Kitaibel (GomBocz 1939) is említi Erdőbénye mellől a Sajgó-hegyről. Ined.: Erdőhorváti: Czink-dűlőből egy egykori szőlődúlő jó állapotú lejtősztyeppjéről került elő kb. 100 töves populációja [7694.4] (FB, ZST 2016).

Orchis purpurea Huds. - Lit.: A Zempléni-hegységből csak a Tokaji-hegyről és a tarcali Terézia-dombról (MOLNÁr V. 2011, BARTHA et al. 2015), valamint Sárospatakról voltak adatai (Tuba Z., [1]). Ined.: Mezőzombor: Harcsa-tető [7893.2] (TMO 2014); Tállya: Nagy-bányász [7793.1] (TMO 2014). Mindkét hely a közelmúltban felhagyott, bolygatott siskanádas szőlőparlag.

Oxybaphus nyctagineus (Michx.) Sweet - Lit.: Legközelebbi előfordulása Nyékládházánál van (TAKÁcs et al. 2013). A Miskolc-Ózd vasútvonalon MoLnÁr \& JUHÁsz (2016), a Miskolc Tiszai pályaudvarról MoLNÁR et al. (2019) jelzi előfordulását. A Miskolc-Nyíregyháza vonalról eddig még nem került elő. Ined.: Tokaj: Vasútállomás közelében, töltésen. [7894.3] (TH 2018, HTIJ).

Peucedanum officinale L. - Lit:: Hegyaljai állományait az alábbi irodalmakból ismerjük: HAZSLINSZKY (1866), KisS (1939) Soó \& HARGITAI (1940), PifKó et al. (2003), MonÁR \& TüRKE (2007), MoLNÁR et al. (2016). Ezeken kívül néhány új helyről is előkerült. Ined.: Erdőbénye: Veres-tető [7794.1] (PZ 2012); Bodrogkisfalud: Csirke-dúlő magasfeszültségú vezeték alatti kaszált irtásrét sávban, Kis-vár siskanádas felhagyott gyümölcsösben [7894.1] (TMO 2014); Legyesbénye: Kő-kút-lapos [7892.4] (VV 2007); Hercegkút: Hosszú-hegy (ZST, SZA 2014).

Polystichum braunii (Spenn.) Fée - Herb.: Hulják (1940): Hollóháza: Komlóska-völgy patak jobb partján (DE-Soó); Kárpáti (1951): Pálháza: Ördög-völgy (DE-Siroki); Vida (1952): Komlóska-völgy, Nagyhuta felé (BPU). Lit.: JÁVORKA a Hegyaljáról írja (1937), KISS (1939) Füzérkomlósról a Török-patak völgyéből említi, Simon Tibor 1961-ben Rostallón (Regéc) az Ördög-völgyben (SIMON 2005b), VojTKó (2008) szintén Regéc környékén találta meg. Ined.: Az országosan is igen ritka faj újabb helyről került elő Telkibánya: Dongó-völgy, bükkösben [7594.1] (PG, SZZS 2011).

Pseudolysimachion longifolium (L.) Opiz - A Bodrog-menti ártéri mocsárrétek és magaskórósok gyakori faja néhol megjelenik a hegylábi és hegység belseji üde élőhelyeken is. $\underline{H e r b .:}$ Kiss (1935): Erdőbényefürdő; Takács (2010): Sátoraljaújhely: Suta-patak (DE-Soó). Lit.: Simon (2005a): László-tanya: Nagy-Álmos rét. Ined.: Erdőbénye: az Aranyosi-völgy felé vezető műút menti árokban több helyen néhány tő: Disznó-dúlő, Lapos-Mogyorós [7794.1], Hangyás-Mogyorós [7793.2] (TIJ 2017).

Pseudolysimachion spurium (L.) Rauschert - A Zempléni-hegységből évtizedekig nem került elő. Legközelebbi adatai a Zempléni-hegység szlovákiai részéről vannak (GoLIAšová 1997), valamint Szendrőről (Budai in Soó 1943), a Putnoki-dombságból (Felsőnyárád) [1] és a Nyírségből származnak (FinTHA 1994). Lit:: HAZSLINSZKY (1866) említi a Zemplén déli részéről, FARKAS (1999) is erre hivatkozva régi adatként említi innen. Ined.: Tállya: Rohos regenerálódó szőlőparlag szélén erdőszegélyben [7793.1] (SuJ 2005, TIJ 2014, HTIJ).

Scabiosa canescens Waldst. et Kit. - Herb.: Siroki (1943): Abaújszántó, Boldogkőváralja (DESiroki); Soó (1948): Abaújszántó: Sátor-hegy (BP). Lit.: Az abaújszántói Sátor-hegyen és Krakón, valamint a boldogkői Vár-hegyen (KISS 1939) ismert. FARKAS (1999) VizsolyHernádcéce térségéből írja. Újabban MolNÁR \& TÜRKE (2007): Hernádcéce, Korlát. Ined.: Abaújkér: Gyưr-völgy erdőssztyeppréten néhány tő [7793.1] (TIJ 2016).

Securigera elegans (Pančić) Lassen - Herb.: Vajda (1949): Pálháza: Csonka-völgy; Borsos (1952): Pálháza: Kőkapu (BPU). Újabban Lovass-Kiss et al. (2011): Makkoshotyka: Kékszűrő (DE-Soó). Lit.: HULJÁK (1938) találja meg először a fajt Magyarországon Erdőhorvátinál, Óhuta felett. SIMON (2005a): Kőkapu (1977), Háromhuta: Nagy-királyos, Kovácsvágás: Szénégető-tető, Sárospatak: Radvány-völgy. Ined.: Újabban több új lelőhelye is előkerült. 
Nagyhuta: Vaskapu-völgy útrézsűben [7694.2] (LL 2013); Makkoshotyka: Nagy-mély-völgy út menti szegélyben [7695.1] (DA, TIJ 2018); Alsóregmec: Cserép-tó [7595.3] (PG, SZZS 2009).

Sedum hispanicum L. - Több régi irodalmi adata van a Hegyaljáról és környékéről, recens adata azonban idáig nem volt. Herb.: Hazsliszky (?): Tokaj (BP). Lit.: KANITZ (1862): Tokaj; HAZSLISZKY (1864, 1866): Tokajtól Korlátig helyenként; JÁVORKA (1925): Hegyalja; Soó \& HARGITAI (1940): Tokaj. Ined.: Hercegkút: Kőporos alja, szőlőparlagok között egy nagy kövön [7695.3] (TIJ, DA 2014). Mivel dísznövényként ültetik, nem zárható ki, hogy csupán kivadulás.

Seseli peucedanoides (M. Bieb.) Koso-Pol. - Lit.: HAZSLINSZKY $(1864,1866)$ írja először a Hegyaljáról a Tokaji-hegyről, ahol 1846-ban találta meg. SimKovics (1877) a Kopasz-hegyen egy délkeleti irányban húzódó sziklasor környékéről írja. HuLJÁK (1926) Tállya: Galamboskő; KISS (1939): Abaújszántó: Fehér-hegy, Krakó-hegy, Sátor-hegy, Boldogkőváralja: Várhegy. A 60-as évekből SIMON (2005b) több helyről közli: Kishuta: Szár-hegy, Tállya: Kopaszhegy. Ined.: A Tokaji-hegy másik részéről, a Kis-kopaszról került elő. Tarcal: Kis-Kopasz [7894.3] (ZST 2006, TIJ 2017).

Sonchus palustris L. - Lit.: A Zemplén déli részéről HAZSLINSZKY (1866) említi. Aktuális adata csak a Hernád-mentéről (FARKAS et al. 2007, MoLnÁR 2014) és a Bodrogközbőll volt (TUBA 2008, BARTHA et al. 2015 [1]). Meglepő, hogy a Cserehátban gyakori faj (BÁNKÚTI \& VojTKó 1995, FARKAS 2011) itt jelentősen megritkul. Ined.: Erdőbényéről került elő a Messzelátó aljából vízállásos medencében, múút mellett (TIJ 2017) [7794.1], továbbá Abaújalpárról a Széles-kötél dűlőből szintén út melletti mocsaras részről (DA 2017) [7693.3].

\section{Bodrogköz}

Acorus calamus L. - Lit.: Morotvákból, csatornákból vannak szórványos adatai (TUBA et al. 2008). Ined.: Dámóc: Motolla [7698.3] (LL 2010); Sátoraljaújhely: Molyva-oldal [7695.2] (LL 2011); Bodrogkeresztúr: Remence [7894.3] (ZST, 2007); Tokaj: Bodrog-part, Felsőlegelő [7894.3] (ZST 2005).

Armoracia macrocarpa (Waldst. et Kit.) Kit. ex Baumg. - Lit.: A Long-erdőből van régi adata (HARGITAI 1940), de onnan azóta nem került elő. TuBA et al. (2008) az egész Bodrogközt megjelöli előfordulási helyeként konkrétumokat nem közölve. Újabban Gyarmati M. flóratérképezési adata ismert Sárospatakról [1]. A Taktaközből és a Tiszántúlról több adata ismert (TAKÁCS \& ZsólYOMI 2011, TAKÁCS et al. 2014). Ined.: Két újabb állománya került elő. Bodrogkeresztúr: Orr-zugi erdő (ZST 2013), itt főként ültetett nemesnyaras alatt fordul elő több ezer tő. A másik lelőhely is hasonló, Bodrogkeresztúr: Remence [7894.1] (TIJ 2017), ahol szintén nemesnyaras, valamint nyiladékok mentén fordul elő ezres nagyságrendủ állománya. A faj az előző előfordulási hely közeléből, a Bodrog túloldaláról is előkerült. Bodrogkeresztúr: Isztru (ZST 2008).

Aster sedifolius L. - Lit.: HAZSLISZKY (1864) Sárospatak környékéről írja. Újabban TUBA et al. (2008) pontosabb helymegjelölés nélkül az alábbi helyekről említi: Bodroghalom, Felsőberecki, Sárospatak, Vajdácska. Ined.: Pácin: Mosonnai-erdő [7697.1] (VV 2012).

Cephalanthera damasonium (Mill.) Druce - A Bodrogközre új! Lit:: TUBA (2008) nem említi monográfiájában. Ined.: Számos új lelőhelyét sikerült kimutatnunk. Sárospatak: Nyugodónyárfás idős nemesnyarasban [7795.1] (LL 2017), Bálványos fiatal nemesnyarasban [7795.4] (LL, TP 2011); Karcsa: Nagy-égés idős kocsányos tölgyes alatt [7796.2] (LL 2017); Lácacséke: Perjai-Alsó-erdő idős kocsányos tölgyesben [7697.4] (LL 2017); Sátoraljaújhely: Long-erdő Gyalmos nevű része idős gyertyános-kocsányos tölgyesben [7695.4] (TIJ 2018). 
Cicuta virosa L. - Lit.: Bodrogkeresztúrról és Sárospatakról régtől ismerjük (GomBocz 1939, KISS 1939, SimON 1952). A Bodrog holtágakból KRICSFALUSY \& MiHALY (2009) jelzi, TuBA et al. (2008): „mocsárrétek, vízpartok ritka növénye, pl. Karcsa part, Olaszliszka, Pácin: Mosonnai-erdő, Rongyva-rétek, Sárospatak, Vadácska. Ined.: Tokaj: Zsaró-ér (ZST 2016), továbbá Bodrogkeresztúrnál a jelenlegi komp mellett van egy nagyobb állománya [7894.1] (TIJ 2018), ahonnan időnként le-le szakad egy-egy egyed, és elvándorol uszadékfán, törmeléken messzebbre. Megtaláltuk a tokaji Felső-legelő mentén is több helyen a Bodrogban (ZST 2016), és a Lebuj-kanyar egyik öblözetében (Remence) is találtunk néhány egyedet [7894.3] (TIJ 2017).

Cirsium brachycephalum Jur. - A Bodrogköz magyarországi részére új! Herb.: Chyzer-től van egy herbáriumi adatunk (1879, BP) Sárospatak környékéről, amelyet tévesen Cirsium palusre-ként cédulázott. Ined.: Sátoraljaújhely: Száraz-rét, ahol közvetlenül a 381-es út mellett van egy 50-60 tőből álló populációja [7696.1] (TIJ 2018). Ez a lelőhely valójában még a Bodrog jobb partján van, de a Bodrog árteréhez tartozik. A 12 km-re lévő szlovákiai Nagygéres és Őrös közötti rétekről, legelőkről említik (VAVRINEC 2016). Tokajnál is előkerült: a Nagy-Nádas-tó melletti nedves réteken néhány tő [7894.3, 7894.4] (TIJ 2017).

Cnidium dubium (Schkuhr) Thell. - $\underline{\text { Herb.: }}$ Soó (1939): Sárospatak: Bodrog holtág menti réten. Lit.: HAZSLISZKY (1864) Olaszliszka, pontosabb helymegjelölés nélkül; Soó \& HARGITAI (1940) Sárospatak: Ó-Bodrog; Simon (1951) Sárospatak: Long-erdő (Boros útinaplója alapján); TUBA et al. (2008): mocsaras területekről említi, főként a Bodrogköz északi részeiről. Számos új helyen megtaláltuk, a Bodrogzug mocsárrétjein általánosan elterjedt faj. Ined.: Sárazsadány: Sárai-zug [7795.3] (TIJ 2015); Olaszliszka: Közép-rét, Szabad-fenék [7794.4] (TIJ 2017); Szegi: Kis-telek [7794.3] (TIJ 2017), Máté-homok; Bodrogkeresztúr: Disznószállás, Bogdány-tói-zug, Malom-szegi-legelő [7894.1] (TIJ 2017); Tokaj: Bodrog-köz [7894.3, 7894.4] (TIJ 2017).

Dianthus collinus Waldst. et Kit. - Lit.: TUBA et al. (2008) jelzi xero-mezofil gyepekből, gátoldalakról Bodroghalász, Sárospatak környékéről. A Bodrog mentén futó árvízvédelmi töltésen nem ritka (pl. Vajdácska gátoldal MolNÁr et al. 2019). Ined.: Sárazsadány: Zsadányhomok; Viss: Hosszú-járó-dűlő [7795.3] (TIJ 2015); Sárospatak: Holtág-erdő [7695.4] (DA 2014).

Dryopteris carthusiana (Vill.) H. P. Fuchs - Lit.: Kevés adata van a Bodrogközből, főként az északi részéről, elsőként Tuba gyűjtötte 1978-ban a zemplénagárdi vadaskertből. Újabban: Dámóc (CSERhAlmi et al. 2006), Karcsa és Sárospatak (GÁL et al. 2006, TuBA et al. 2008). A Long-erdőből elsőként KEVEY (2018) közli, adatát mi is megerősítettük. Ined.: Sátoraljaújhely: Long-erdő Kökényes és Gyalmos nevű részén [7695.4] (TIJ 2018). Bodrogkeresztúr: Disznó-szállás, idős kocsányos tölgyfasor alatt; Remence a Bodrog partján uszadékfákon [7894.1] (TIJ 2017).

Dryopteris dilatata (Hoffm.) A. Gray - Az előzőnél jóval ritkább faj a Bordogközben. Lit.: TUBA et al. (2008) is csak Seregélyes Tiborra (in FARKAS 1999) utalva említi meg Dámócról és Révleányvárról. Ined.: Bodrogkeresztúr: Remence a Dryopteris carthusiana-k mellett uszadékfán [7894.1] (TIJ 2017); A Sátoraljaújhelyi Long-erdőből is előkerült az Új-Bodrog melletti ligeterdőből, ahonnan eddig nem volt adata [7695.4] (TIJ 2018).

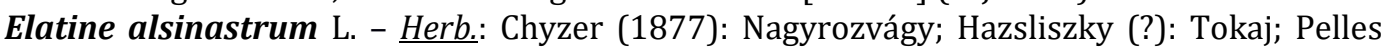
(1998): Pácin (BP). Lit.: Régebbi irodalmi adatait TuBA et al. (2008) összegzi, ő iszapnövényzetben, belvizes szántókról írja a Bodrogköz északi részéről. CsERHALMI et al. (2006) helyenként gyakorinak írja. NAGY (2006) a Szennatanya belvizes szántójáról és Cigánd mellett, a Tisza mentett oldali kubikgödréből közli Elatinetum alsinastri (2006) original diagnózisát. Ined.: Zalkod: Fenyér (ZST, PZ 2007); Olaszliszka: Szabad-fenék, keréknyomban kialakult iszapnövényzetben [7794.4] (TIJ 2018). Sátoraljaújhelyről a Long-erdő Oroly nevű részéből is előkerült (TIJ 2018), szintén keréknyomból. 
Epilobium palustre L. - A Bodrogközre új! Legközelebbi adatai a Zempléni-hegységből (ld. fent) és a Taktaközből vannak (ld. lejjebb). Ined.: Pácin: Égeres, Kis-Karcsa, Nagy-Karcsa feltöltődő holtmedrekben [7697.1] (VV 2012).

Epipactis helleborine Cr. - Lit.: TUBA et al. (2008) több helyről is említi. Ined.: Sátoraljaújhely: Long-erdő Oroly nevű részén nemesnyaras alatt több száz tő, Gyalmos idős keményfás ligeterdő szegélyében út mellett [7695.4] (TIJ 2017); Sárospatak: Nyugodó-nyárfás [7795.1]; Karcsa: Becskedi-erdő [7696.4], Nagy-égés [7696.2]; Dámóc: Vadaskert [7698.1]; Lácacséke: Perjei Alsó-erdő [7697.4] (LL 2017).

Epipactis palustris (Mill.) Cr. - A Bodrogközre új! Ined.: Az országos szinten is jelentős, közel 3500 tőből álló populációra Verbinyecz Róbert talált rá Kisrozvágy mellett a Sasó-homok dűlőben. Az állomány egy mesterségesen létrehozott kiszáradó füves lecsapoló árokban található, amelyet rendszeresen égetnek [7697.4] (VR 2018). Úgy tűnik az égetés volt e populáció fennmaradásának kulcsa, hiszen a környék hasonló, de nem kezelt árkaiban nem találtuk a fajt.

Epipactis tallosii A. Molnár \& Robatsch - Lit.: CSERHALMI et al. (2006): Pácin: Kastélyerdő. TUBA et al. (2008): Sárospatak: Ó-Bodrog, Nyáras. Zemplénagárdi erdő. Tapasztalataink szerint a bodrogzugi részen nem ritka, 2017-ben néhány hét alatt célzott terepbejárással 4 új lelőhelyére bukkantunk. Mi szinte minden esetben a Bodrog menti keskeny sávban húzódó puhafás állományokban, illetve azok szegélyzónájában, gyakran gyalogakácos alkotta szegély alatt találtuk meg töveit. Ined.: Sárospatak: Nyugodó-nyárfás [7795.1] (LL 2017); Olaszliszka: Hamarlátó-fenék, Szabad-fenék, Szabad-szállás, Alsó-erdő Kapronca mellett [7794.4] (TIJ 2017); Bodrogkeresztúr: Remence [7894.1] (ZST 2012, TIJ 2017), [7894.3] (ZST 2012); Tokaj: kertekben spontán, kerékpárút mellett [7894.3] (ZST 2005). Utóbbi lelőhely a Bodrog jobb parti ártere és a Tokaji-hegy lábának találkozásánál helyezkedik el.

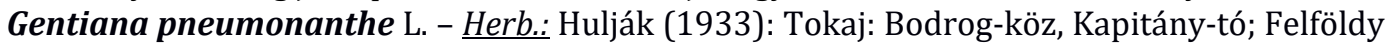
(1993): Olaszliszka: Rét-alja; Molnár \& Sulyok (1993): Olaszliszka: Fekete-tó (BP). Lit.: Irodalmi adatainak összegzése mellett TuBA et al. (2008) mocsári és ártéri erdők ritka, védett növényeként említi a következő helymegjelölésekkel: Bodrogzug, Bodrog ártér, a Bodrog és a Nagy-tó között, Bodrogolaszival szemben a Bodrog mentén a Bodrogzugig, Olaszliszka: mocsárrét, Ricse környéke. KISS (1939): Sárospatak: Bodrog-part, FINTHA (1994): Sárospatak és Sátoraljaújhely közötti Rongyva-réteken, Long-erdő szélein. Jelen adatunk Hulják herbáriumi adatának (1933) megerősítése. Ined.: Tokaj: Felső-legelő 1-2 tő [7894.3] (ZST 2005), Bodrog-köz [7894.3] (PZ, HF 2015).

Hottonia palustris L. - Herb.: Pelles (1998): Lácacséke: Bélyi-csatorna, Ricsei főcsatorna (BP); Szabolcs \& Zsólyomi (2013): Dámóc (DE-Soó). Lit.: CHYZER (1905) említi először a Bodrogközből, Nagygéres és Rozvágy között. Újabban Vissről és Zemplénagárdról említi CSERHALmi et al. (2006) valamint TUBA et al. (2008) a következő helyekről: Őr-hegy: Monyha-tanya, Bélyi-csatorna, Karádi-csatorna. Ined.: Cigánd: Médium-csatorna [7797.1] (HA, ZST 2014); Pácin: Mosonnai erdő Karcsa-ér [7697.1] (LL, TP, ZST 2011).

Iris sibirica L. - Lit.: FARKAS (1999): Bodrogszegi, TUBA (1994): Bodrogköz, pontos helymegjelölés nélkül. Ined.: Olaszliszka: Közép-rét [7794.4] (TIJ 2015); Vámosújfalu: Kis-rét [7795.1] (DA 2016).

Lathyrus nissolia L. - Régi irodalmi adatai nincsenek a Bodrogközből. Gyarmati M. több helyen is megtalálta: Kenézlő, Bodroghalom, Karcsa [1]. Ined.: Karos: Eperjes-szög [7696.3]; Pácin: Biharom-dűlő [7796.2], Rongyva-oldal [7697.3] (DA, TP 2016).

Lathyrus palustris L. - Lit.: HARGITAI (1939): Sátoraljaújhely: Long-erdő. A Bodrogközből említi FARKAS (1999). Újabban SzIRMAI et al. (2006): Tokaj: Zsaró-ér; TuBA et al. (2008): Alsóberecki, Bodroghalom, Révleányvár, Ricse, Sárospatak mocsárrétjeiről említi. Ined.: Bodrogkisfalud: Keselyűs [7794.4] (ZST 2012); Zalkod: Csenke D-i része a falu határában [7894.2] (TIJ 2015); Tokaj: Bodrogzug [7894.3] (TIJ 2017); Olaszliszka: Dió-ér [7794.4] 
(DA 2017); Sátoraljaújhely: Long-erdő Gyalmos [7695.4] (TIJ 2018); Karcsa: Lábszár [7696.4] (TIJ 2018). Mocsárrétekről, magaskórósokból.

Leucanthemella serotina (L.) Tzvelev - Lit.: Számos adata ismert a Tisza és a Bodrog mentén (HARGITAI 1939): Sátoraljaújhely: Long-erdő; KISS (1939): Bodrog-holtágak, Bodrogkeresztúr; Soó \& HARGITAI (1940): Tokaj. Újabban TUBA et al. (2008): az egész Bodrog mentén gyakori fajnak írja le. Ined.: Sárazsadány: Vámosi-rét [7794.2] (SJ 2017); Sárazsadány: Zsadány-homok, Sárai-zug; Viss: Csonkás [7795.3] (TIJ 2015); Tokaj: Bodrog-köz [7894.3] (TIJ 2017).

Leucojum aestivum L. - Lit.: TUBA et al. (2008) összegzi irodalmi adatait a Bodrogközből. Puhafa ligetek nem ritka fajának írja, Alsóberecki, Bodroghalom, Bodroghalász, Felsőberecki, Gelind, Olaszliszka, Sárospatak: Ó-Bodrog felső végi kaszálórét helymegjelölésekkel. Ined.: Sátoraljaújhely: Pap-erdő [7695.2] (LL 2016); Mocsolya [7696.3] (LL, TP 2011); Felsőberecki: Bodrog hullámtér [7696.1] (LL, PZ 2011); Szegi: Faragó-szállás [7794.3] (TIJ 2017); Tokaj: Nagy-Nádas-tó [7894.3] (TIJ 2017); Zemplénagárd: Kati-kert [7698.4] (LL 2017).

Lindernia procumbens (Krock.) Philcox - Herb.: Hazsliszky (?): Bodrogköz, Tokaj; Pelles (1998): Bodrogolaszi. Lit.: Több helyről ismert a Bodrogközből (ld. TuBA et al. 2008). Ined.: Sárospatak: Apró-homok [7795.2] (ZST 2010); Kenézlő: Hosszú-dűlő [7795.3]; Tiszakarád: Északi-forda [7796.1]; Zemplénagárd: Kóróska [7698.4] (PG 2010).

Listera ovata (L.) R. Br. - Lit.: A Zempléni-hegységben nem ritka orchidea fajnak a Bodrogközből alig van adata, Sulyok in FARKAS (1999): Lácacséke pontosabb helymegjelölés nélkül; Мıно́к (2004), KEVEY et al. (2018): Sátoraljaújhely Long-erdő. Ined.: 2017-ben több helyről is előkerült. Sárospatak: Nyugodó-nyárfás idős nemenyaras alatt [7795.1]; Lácacséke: Perjei-alsó-erdő [7697.4]; Révleányvár: Motolla [7698.3] (LL 2017), idősebb kocsányostölgyes erdőkben.

Lycopodium clavatum L. - A Bodrogközre új! Lit.: Az Észak-Alföldön FinTHA (1994) találta először, Csaholcnál. Azóta csak Gulyás G. találta Kispaládon [1]. Ined.: Pácin: Mosonnaierdő, keményfaligeterdő szélén, kisavanyodó mohás részen [7697.1] (SZZS 2013).

Marsilea quadrifolia L. - Herb.: Egey (1932), Újvárosi (1939), Vajda (1946), Bánó (1948): Sárospatak: Bodrog; Egey (?): Sárospatak: Berek; Kárpáti (1952): Sárospatak: Füzes-ér. Lit.: Újabban SziRMAi et al. (2006) Bodroghalász-Kengyel holtág, Ricse: Pallagcsa-rét, Sárospatak: Ó-Bodrog. TUBA et al. (2008) számos új helyről is megemlíti, pontosabb helymegjelölés nélkül: Alsóberecki, Bodroghalász: Szög, Bodroghalom, Felsőberecki: csatorna, Karcsa, Olaszliszka, Pácin, Ronyva-rétek, Sárospatak: Füzes-ér, Ó-Bodrog, Tokaj: Zsaró-ér, Törökér, Vajdácska, Ined.: Az olaszliszkai adatot pontosítottuk: Olaszliszka Fekete-tó néhány egyed [7794.4] (ZST 2012).

Neottia nidus-avis (L.) Rich. - Lit.: Мıно́к (2004): Sátoraljaújhely: Long-erdőből jelzi. TuвA et al. (2008) a Bodrogköz területéről írja ritka fajként, Sárospatak: Ó-Bodrog. Ined.: Sátoraljaújhely: Long-erdő, Gyalmos, idős keményfa ligetben [7695.4] (TIJ 2017); Sárospatak: Nyugodó-nyárfás, idős nemesnyarasban [7795.1] (LL 2017).

Nymphoides peltata (S. G. Gmel.) Kuntze - Lit.: FARKAS (1999): Bodrogkeresztúr, TuBA et al. (2008): Bodrogzug: Kapitány-tó, Karcsa-csatorna, Olaszliszka, Tokaj: Zsaró-ér. Ined.: Zalkod: Dió-ér [7894.2] (PZ 2012); Bodrogkeresztúr: Disznó-szállás mocsárban [7894.1] (TIJ 2019).

Ophioglossum vulgatum L. - Lit.: A Bodrogközből először KEVEY (2015) közli a sátoraljaújhelyi Long-erdőből. A kistájban mi is számos helyen megtaláltuk az utóbbi években. Valószínűleg sok helyen megvan, azonban mivel nehezen észrevehető faj, kevés adatunk van róla. Mocsárrétekben, ligeterdők, nemesnyarasok aljnövényzetében éppúgy megtalálható, mint inváziós állományok alatt. Ined.: Bodrogkisfalud: Kis-Balota idős tölgyes maradványfolt alatt több száz tő, Nagy-Balota-erdő nemesnyaras alatt néhány tő, Bodrogkeresztúr: 
Remence, a Kakukk-tó melletti mocsárrétben nem mentett oldalon néhány tő [7894.1] (TIJ 2017, 2018); Sátoraljaújhely: Long-erdő: Nagy-Gyalmos tó mellett spontán amerikai kőrises alatt [7695.4] (TIJ 2017); Olaszliszka: Szabad-fenék gyalogakácos alatt nem ritka [7794.4] (TIJ 2018).

Orchis morio L. - Lit.: A Bodrogközből egyedül TUBA et al. (2008) említi, így fogalmaz: „Viss, Zalkod, Kenézlő környékén homoktalajon régebben előfordult”. Ined.: Sárospatak: Gubástónál Füssi-Nagy Szabolcs hívta fel figyelmünket a faj néhány egyedére legeltetett homoki gyepben [7795.3] (FNSZ 2018).

Polystichum aculeatum (L.) Roth - A Bodrogközre új! Lit.: FINTHA (1994) találja meg először az Észak-Alföldön Turricsén, a Ricsei-erdőben. Király G. (in BARTHA et al. 2015) Baktalórántházáról jelzi. A közelben még Tokaj Nagy-Kopasz: Lencsés-völgyből (TAKÁcs et al. 2016), illetve a Tarmag-bányából és a Rákóczi-völgy vízmosásból (ZST 2005) ismert az előfordulása. Ined.: Révleányvár: Motolla tölgyesben [7698.3] (VV 2012).

Pseudolysimachion longifolium (L.) Opiz - A Bodrogköz ártéri rétjein, magaskórósaiban gyakori faj. Lit.: Irodalmi adatait TUBA et al. (2008) összegzi mocsárrétekről, magaskórósokból jelzi: Bodroghalász: Kengyel-holtág, Borogkeresztúr: mocsárrét, Török-ér, Vajdácska helymegjelölésekkel. Ined.: Sárazsadány: Sárai-zug [7795.3] (TIJ 2015); Bodrogkeresztúr: Disznó-szállás, Bogdány-tói-zug [7894.1] (TIJ 2017); Tokaj: Bodrog-köz [7894.2, 7894.3, 7894.4].

Pyrola rotundifolia L. - A Bodrogközre új! Lit.: Főként hegyvidéki mészkerülő erdei faj, igen ritka az Alföldön. Eddig csak Bátorligetről volt adata (RÉv et al. 2006). Ined.: Sárospatak: Nyugodó-nyárfás, Bodrogolaszi: Horgas [7795.1] (LL 2017); Bálványos [7795.4] (PG, SZZS 2011) idős nemesnyarasokban. Ahogy Rév et al. (2006) is jelzi, előfordulása a nyárfatelepítéssel is összefügghet.

Ranunculus lingua L. - Szórványos előfordulású. Lit.: TUBA et al. (2008) közöl a fajról adatokat: Olaszliszka-Bodrogzug, Tokaj: Zsaró-ér, ez utóbbi adatát mi is megerősítettük. Ined.: Tokaj: Zsaró-ér [7894.1] (ZST 2006, HTIJ); Bodrogkisfalud: Macskás, Kásod-rét (PZ 2012, 2014); Bodrogkeresztúr: Longi-ér (ZST 2012) [7894.2].

\section{Taktaköz, Harangod}

Cirsium brachycephalum Jur. - Lit.: Több adata ismert: Mezőzombor (MOLNÁR \& TÜRKE 2007), Bekecs, Legyesbénye (TAKÁcs et al. 2014) a környékéről. Ined.: Előkerült a Harangodból, Szerencs mellől is: Békás-dűlő, Mohos-dűlő [7893.3] (ZST 2012).

Clematis integrifolia L. - Lit:: A Harangodból több helyről említi MoLnÁR (2014). A Taktaköznek csak a déli részéről (Kesznyéteni TK és környéke) ismert (TAKÁcs et al. 2014). Ined.: Mezőzombor: Berzse [7893.2], Sár-rét [7893.4] (ZST 2010, 2012).

Cnidium dubium (Schkuhr) Thell. - Lit.: TAKÁcs et al. (2014) számos adatot közöl a Taktaközből (Csobaj, Mezőzombor-Tarcal, Taktakenéz, Tiszadob, Tiszalúc, Tiszaújváros). Ined.: Tiszaladány: Kis-virágos dúlő, fasor szélén, fajszegény mocsárréten néhány tő [7994.1] (TIJ 2018).

Eleocharis uniglumis (Link) Schult. - Lit.: TAKÁCS et al. (2016): Kesznyéten. Ined.: A Taktaköz és a Harangod határáról került elő: Legyesbénye: Kő-kút-lapos, szikesedő gyep mélyedéseiben [7892.4] (VV 2007).

Epilobium palustre L. - A Taktaközre új! Legközelebb a Zempléni-hegységből és a Bodrogköz északi részeiről (lásd fent) vannak adatai, illetve a Hernád-völgyből, Aszaló mellől (Molnár Cs. flóratérképezési adata [1]). Ined.: Tiszaladány: Sulymos gyékényesben Thelypteris palustris-ok társaságában [7994.1] (TIJ 2018, HTIJ). 
Epipactis tallosii A. Molnár et Robatsch - Lit.: A Taktaközben csak néhány helyről került eddig elő: Prügy (TAKÁCS \& ZsólYOMI 2010), Tiszalök (TAKÁCS et al. 2014). A Bodrogközben viszonylag gyakori a Bodrog menti puhafás állományok szélén (lásd fent). Ined.: Tiszaladány: Kubikos [7994.2] (TIJ 2018) 100 körüli tő idősebb puhafaligetben.

Iris spuria L. - Lit.: A Taktaköz déli részén (Kesznyéteni TK) régóta ismert (MoLNÁR 1996). FARKAS (1999) említi a Taktaközből, Mezőzomborról (de az adat pontosabban, formálisan soha nem került közlésre). Újabban Tiszadob: Ó-Kenéz (MolNÁR et al. 2017) és Csobaj mellől került elő (TAKÁcs et al. 2014) a Tisza menti töltésről (ez az állomány a közelmúltbeli töltésfejlesztés miatt valószínűleg elpusztult). A Harangodról nem ismerjük korábbi adatát. Ined.: Mezőzombor: Sár-rét [7893.4] (ZST 2010), Berzse [7893.2] (ZST 2012) (lényegében FARKAS 1999 adatának pontosítása, aktualizálása); Legyesbénye: Kender-szeri-dűlő [7892.4] (SJ 2008) mocsárréteken.

Lathyrus nissolia L. - Lit.: A Taktaköz déli részéről (Kesznyéteni TK) TAKÁCS et al. (2014), közelebbről, Tarcal mellől MoLnÁR et al. (2016) közölték. Ined.: Tiszaladány: Tölgyes girind [7994.1] (PZ 2013).

Lindernia procumbens (Krock.) Philcox - Lit.: Több adata ismert a Taktaközből és környékéről (TAKÁCS \& ZsóLYOMI 2011, TAKÁCS et al. 2013, 2014). Ined.: Mezőzombor: Fecskés-dűlő [7893.3] (ZST 2010).

Sonchus palustris L. - A Taktaközre új! Lit.: Legközelibb adatait MoLNÁR (2014) (Alsódobsza) és Sulyok J. (flóratérképezési adat [1]) jelezték. Ined.: Mezőzombor: a temető közelében a Sár-rét szélén egy nagyobb állomány (DA 2019).

Urtica kioviensis Rogow. - Lit.: A Taktaköz déli részéről (Kesznyéteni TK) ismert [1]. Ined.: Mezőzombor: Nagy-tó [7893.4] (ZST 2010); Szerencs: Pásztor-tó [7893.3] (ZST 2010); Tiszaladány: Tiszaladányi-Holt-Tisza [7994.2] (ZST 2010).

\section{Köszönetnyilvánítás}

Ezúton mondunk köszönetet Bereczki Attilának, Béres Istvánnak, Barati Sándornak, Éles Eszternek, Fakla Bélának, Farkas Rolandnak, Füssi-Nagy Szabolcsnak, Herceg Ferencnek, Halász Antalnak, Huber Attilának, Kóra Juditnak, Nagy Gábornak, Petrovics Zoltánnak, Sulyok Józsefnek, Sztuhai Anettnek, Szegedi Zsoltnak, Thomas Haberlernek, Tóth Péternek, Verbinyecz Róbertnak és Virók Viktornak, akik lehetővé tették, hogy publikálatlan adataikat leközöljük. Köszönjük a terepmunkában való részvételét Repka Eszternek. Külön köszönjük Virók Viktornak és Takács Attilának, hogy bátorítottak, támogattak és segítettek a munka elkészítése során. A digitális herbáriumi adatok rendelkezésünkre bocsátásáért Takács Attilának, Molnár V. Attilának és Nótári Krisztinának tartozunk köszönettel. A Magyar Flóratérképezési Adatbázis háttéradatait Schmidt Dávidnak köszönhetjük. A fajok határozásában segítségünkre volt Virók Viktor, Takács Attila, Farkas Tünde, Sramkó Gábor és Exner Tamás, akiknek ezúton is köszönjük a segítségüket. Külön köszönjük a nőszőfüvek határozásában nyújtott segítségét Molnár V. Attilának és Makádi Sándornak. Alapos lektori munkájáért köszönettel tartozunk Molnár Csabának és Nagy János Györgynek.

\section{Irodalom}

BÁNKÚTı K. \& VojTKó A. (1995): Adatok a Sonchus palustris L. elterjedéséhez. - Folia Historico Naturalia Musei Matraensis 20: 49-50.

BARATI S., HudÁK K. \& ÉzSöL T. (2009): Növénytani és madártani adatok a monoki Őr-hegy és Szőlőshegy területéről. - Folia Historico Naturalia Musei Matraensis 30: 415-421. 
BARINA Z. (2009): Brassicaceae (Cruciferae) - Keresztesvirágúak családja. In: KIRÁLY G. (szerk.), Új magyar füvészkönyv. Magyarország hajtásos növényei. Határozókulcsok. - Aggteleki NPI, Jósvafő.

BARTha D., Király G., SchmidT D., TiborCZ V., BARina Z., CSiky J., JAKAB G., LESKu B., SChMotZer A., VidéKi R., Vojткó A. \& ZólYomi Sz. (szerk.) (2015): Magyarország edényes növényfajainak elterjedési atlasza. Nyugat-magyarországi Egyetem Kiadó, Sopron, 329 pp.

BERTOVÁ L (szerk) (1988): Flora Slovenska IV/4. - Veda, Bratislava.

Bertová L (szerk) (1992): Flora Slovenska IV/3. - Veda, Bratislava.

Boros Á. (1930): A Nyírség flórája és növényföldrajza. - Stúdium Könyvkiadó Rt., Budapest.

Boros Á. (1970): Florisztikai közlemények V. - Botanikai Közlemények 57(1): 69-72

BoRsos O. (1959): Geobotanische monographie der orchideen der pannonischen unfkarpatischen flora II. - Annales Universitatis Scientiarum Budapestinensis de Rolando Eötvös 2: 59-93.

CHYZER K. (1905): Adatok északi Magyarország, különösen Zemplén megye és Bártfa sz. kir. város flórájához. - Magyar Botanikai lapok 4(12): 304-331.

Cserhalmi D., Nagy J., Szirmai O., GÁl B., Czóbel Sz., Szerdahelyi T., Ürmös Zs. \& Tuba Z. (2006): Új florisztikai adatok a magyarországi Bodrogköz területéről. - Folia Historico Naturalia Musei Matraensis 30: 71-73

Csiky J., Baráth K., Csikyné Radnai E., Deme J., Wirth T., Zurdo J. A. \& Kovács D. (2018): Pótlások Magyarország edényes növényfajainak elterjedési atlaszához VIII. - Kitaibelia 23(2): 238-261.

E. VojtKó A., TAKÁCS A., Molnár V. A. \& VojtKó A. (2014): Herbarium database of the vascular collection of Eszterházy Károly College (EGR). - Kitaibelia 19(2): 339-348.

FARKAS J. (2010): A Hernád és környékének vegetációja. In: MolnáR Cs., MolnáR Zs. \& VARGA A. (szerk.), Válogatás az első 13 MÉTA-túra túrafüzeteiből 2003-2009. - MTA-ÖBKI, Vácrátót, pp. 389-391.

FARKAS S. (szerk.) (1999): Magyarország védett növényei. - Mezőgazda Kiadó, Budapest.

FARKAS T. (2011): Adatok Borsod-Abaúj-Zemplén megye flórájához I. - Kitaibelia 15(1-2): 167-179.

FinTHA I. (1994): Az Észak-Alföld edényes flórája. - TermészetBúvár Alapítvány Kiadó, Budapest.

FuTÁK J. (1966): Flora Slovenska II. - Veda, Bratislava.

FUTÁK J. (1982): Flora Slovenska III. - Veda, Bratislava.

Gál B., Szirmai O., Czóbel Sz., Cserhalmi D., Nagy J., Szerdahelyi T., Ürmös Zs. \& Tuba Z. (2006): Jellegzetes gyep- és erdőtársulások a magyarországi Bodrogközben. - Folia Historico Naturalia Musei Matraensis 30: 43-62.

GoLIAŠovÁ K. (1997): Flora Slovenska V/2. - Veda, Bratislava.

Goмвосz E. (1939): Kitaibel Pál: Iter Bereghiense 1803. A Hegyaljára vonatkozó naplórészletek. Botanikai Közlemények 36: 273-296.

HALÁsz A. (2008): A Blechnum spicant (L.) Roth megjelenése a Zempléni-hegységben. - Kitaibelia 13(1): 162.

HARGitai Z. (1939): A Long-erdő és vegetációja. - Acta Geobotanica Hungarica 2(2): 143-149.

HARGitAi Z. (1940): A sárospataki előhegyek vegetációja. - Acta Geobotanica Hungarica 3(1): 18-29.

HARGITAI Z. (1944): Mikroklíma vizsgálatok a Sátorhegységben Sárospatak környékén. - Acta Geobotanica Hungarica 5(2): 290-312.

HAZSLINSZKY F. (1864): Éjszaki Magyarhon viránya. - Éjszaki Magyarhon viránya, Kassa.

HAZSLINSZKY F. (1866): A Tokaj-Hegyalja viránya. - Mathematicai és Természet Tudományi Közlemények 4: 105-143.

HULJÁK J. (1926): Florisztikai adatok a Gömör-Szepesi Érchegység és az Eperjes-Tokaji hegylánc területének ismeretéhez. - Magyar Botanikai Lapok 25: 266-269.

HuLjÁK J. (1938): Coronilla latifolia és néhány más adat a Hegyaljáról. - Botanikai Közlemények 36: 325.

HuLJÁK P. (1997): Néhány újabb adat a Zempléni-hegység dendroflórájának ismeretéhez. - Kitaibelia 2: 44-45.

JávorKa S. (1912): Az Erysimum erysimoides (L.) Fritsch csoportról. - Magyar Botanikai Lapok 11: 20-35.

JÁVORKA S. (1925): Magyar flóra (Flora Hungarica). - Stúdium, Budapest.

JÁVoRKA S. (1935): Újabb érdekes növényelőfordulások. - Botanikai Közlemények 32(1-6): 161-163.

JÁVoRKA S. (1937): A Magyar flóra kis határozója. 2. kiadás. - Stúdium, Budapest.

KÁllaYnÉ Sz. J. (2018): A bordapáfrány (Blechnum spicant) új előfordulási adata a Zemplénihegységből. - Aktuális flóra és vegetációkutatások a Kárpát-medencében XII. Konferencia kötet, Debrecen, p. 72.

KANITZ Á. (1862): Reliquiae Kitaibelianae. - Apud Guil. Braumüller, Bécs. 
KEVEY B. (2015): Adatok Magyarország flórájának és vegetációjának ismeretéhez X. - Botanikai Közlemények 102(1-2): 39-60.

Kevey B. (2017): Pótlások Magyarország edényes növényfajainak elterjedési atlaszához IV. - Kitaibelia 22(2): 358-382.

KiRÁlY G. (szerk.) (2009): Új magyar füvészkönyv. Magyarország hajtásos növényei. Határozókulcsok. Aggteleki NPI, Jósvafő.

KISS Á. (1939): Adatok a Hegyalja flórájához. - Botanikai Közlemények 36: 180-273.

KRICSFALUSY V. \& Mihaly A. (2009): Flora and vegetation of the Bodrog catchment area (International expedition to the Upper Tisza region. - Thaiszia Journal of Botany 19: 135-151.

LAKATOS E. (1975): A szerencsi szigethegység és a határos Hernád-völgy növénytársulásai. - Abstracta botanica 3: 113-120.

MARgitTAi A. (1933): Addimenta ad floram Carpatorum Septentrionali-orientalium. - Magyar Botanikai Lapok 32: 95.

MARGiTTAI A. (1938): Az Északkeleti-Kárpátok néhány érdekes növénye. - Botanikai Közlemények 35: 58-63.

MARSCHALl Z. \& TUBA Z. (2009): New botanical data to the northeastern margin of Hegyalja (Zemplén Mountains, Hungary). - Thaiszia Journal of Botany 19(1): 39-47.

MARSCHALl Z. (2004): Az Iris aphylla subsp. hungarica (W. et K.) Hegi újabb előfordulása a Zemplénihegységben. - Acta Acad. Paed. Agriensis, Sectio Biologiae 24: 39-42.

Matus G., Aszalós R., Dorotovic Cs., Hanyicska M., Hűvös-Récsi A., Musicz L., Miglécz T., Papp M., Schmotzer A., Török P., Valkó O., Vojtkó A., Harmann J., TAKÁcs A. \& Balogh R. (2019): Kiegészítések a magyar flóra ismeretéhez. - Botanikai Közlemények 106(1): 71-112.

Matus G., SRAmkó G., PAPP B. \& LőKÖS L. (2005): Woodsia ilvensis (L.) R. Br. új előfordulása az EperjesTokaji-hegységben. - Kitaibelia 10 (1): 18-23.

MATus G., SZILÁGYI G. \& TóthmÉRÉsz B. (1993): A Gyertyánkúti-rétek rekonstrukciós terve. - Kutatási jelentés a BNP igazgatósága részére, Debrecen.

MichALKOVÁ E. (1999): Erysimum pallidiflorum Jáv. (Brassicaceae) na Slovensku. - Ochrana př́rody 17: $39-47$.

Mıнóк I. (2004): A Long erdő Természetvédelmi Terület állapotfelvétele és kezelési terve. - Diplomadolgozat, Sopron.

MolnÁR Cs. \& JuHÁsz M. (2016): Az alacsony libatop (Chenopodium pumilio R.Br.) Zuglóban és új adatok Északkelet-Magyarország idegenhonos fajainak elterjedéséhez. - Kitaibelia 21(2): 221-226.

MolNÁR Cs. \& TÜRKE I.J. (2007): Adatok az Eperjes-Tokaji-hegylánc déli felének növényvilágából. Kitaibelia 12(1):108-115.

MoLNÁR Cs. (2014): Florisztikai adatok a Harangod és a Dél-Cserehát löszvidékéről. - Kitaibelia 19(1): 105-113.

Molnár Cs., Haszonits Gy., Malatinszky Á., Kovács G. K., Kovács G., NaGy T., Molnár V. A. \& TakÁcs A. (2017): Pótlások Magyarország edényes növényfajainak elterjedési atlaszához III. - Kitaibelia 22(1): 122-146.

Molnár Cs., Haszonits Gy., Malatinszky Á., Süveges K., Balogh L., Nagy T., Horváth S. \& HudÁk K. (2018): Pótlások Magyarország edényes növényfajainak elterjedési atlaszához VI. - Kitaibelia 23(1): 87-102.

Molnár Cs., Haszonits Gy., Pintér B., Korda M., Peregrym M., Nótári K., Malatiszky Á., Toldi M. \& Beránek Á. (2019): Pótlások Magyarország edényes növényfajainak elterjedési atlaszához IX. - Kitaibelia 24(2): 253-256.

Molnár Cs., Lengyel A., Molnár V. A., Nagy T., CsÁbi M., Süveges K., Lengyel-Vaskor D., Tóth Gy. \& Takács A. (2016): Pótlások Magyarország edényes növényfajainak elterjedési atlaszához II. - Kitaibelia 21(2): 227-252

MoLnÁR V. A. (2011): Magyarország orchideáinak atlasza. - Kossuth Kiadó, Budapest 504 pp.

MolnÁr V. A., VlCKO J., Pelles G. \& FARKAS S. (2000): Epipactis albensis Novakova \& Rydlo a Zemplénihegységben. - Kitaibelia 5(2): 369.

NAGY G. (2011): Mogyoróska és környéke. A Regéc-Mogyoróskai kismedence növényvilága és Mogyoróska múltjának bemutatása a történeti földrajz szemszögéból nézve. - Saját kiadás, Mogyoróska.

Nagy J., Szerdahelyi T., Gál B., Czóbel Sz., Szirmai O., Tuba Z., Cserhalmi D. \& Ürmös Zs. (2006): Új növénytársulások a magyarországi Bodrogközben: előzetes közlemény. - Folia Historico Naturalia Musei Matraensis 30: 63-69. 
NAGY T., Bódis J., Biró É., Gerner G., Simon Zs., SzABó I. \& TAKÁCS A. (2018): Magyar herbáriumok 16. A keszthelyi Georgikon Kar herbáriuma (GK). - Botanikai Közlemények 105(2): 223-230.

NAGY T., TAKÁCS A. \& BóDIS J. (2016): Magyar herbáriumok 15. A keszthelyi Balatoni Múzeum herbáriuma (KBM). - Botanikai Közlemények 103(2): 213-226.

NiKLFELD H. (1971): Bericht über die Kartierung der Flora Mitteleuropas. - Taxon 20(4): 545-571.

NótÁRI K., NAGY T., LÖKI V., LJUBKA T., MOLNÁR V. A. \& TAKÁCS A. (2017): Az ELTE Füvészkert herbáriuma (BPU) - Kitaibelia 22(1): 55-59.

PATALENSZKY N. (2012): Védett növények új előfordulási adatai a Zempléni-hegység nyugati részén. Kutatási jelentés, „Nemzeti Kiválóság Program” - TÁMOP.

PELLES G. (1997): Karcsú nőszőfü (Epipactis gracilis B. \& H. Baumann) a Sátor-hegységben. - Kitaibelia 2: 38.

Penksza K. \& Salamon G. (1997): Adatok a Cserehát, a Bódva-völgy és a Rakacai-völgymedence flórájához II. - Kitaibelia 2(2): 231-232.

Penksza K. \& Somlyay L. (1999): A Geum rivale L. felfedezése Magyarországon. - Kitaibelia 4(2): 273275.

PIFKÓ D., SOMLYAY L. \& LőKÖs L. (2003): Adatok a Zempléni-hegység flórájához. - Kitaibelia 8(1): 187.

RÉV Sz., PAPP M., LESKU B. \& BUDAY A. (2006): A bátorligeti Fényi-erdő flórája. - Kitaibelia 10(1): 48-64.

SimKovics L. (1877): A Tokaj-Hegyalja néhány növényéről. - Magyar Növénytani Lapok 1(10): 165-167.

Simon T. (1971): Mohagazdag szilikátsziklagyepek a Zempléni-hegységben. - Botanikai Közlemények 58(1): 33-45.

Simon T. (1977): A Zempléni-hegység északi részének védendő flóra különlegességeiről. - Abstracta Botanica 5: 57-63.

Simon T. (1992): A magyarországi edényes flóra határozója. - Tankönyvkiadó, Budapest.

Simon T. (2005a): Botanikai útinaplóim Zempléni-hegységi adatai (1954-1967). - Kanitzia 13: 11-28.

Simon T. (2005b): Adatok a Zempléni-hegység flórájához (1950-1980) és a Carpaticum flórahatár kérdése. - Botanikai Közlemények 92(1-2): 69-84.

Simon T. (2006): A Zempléni-hegység botanikai értékei. - Folia Historico Naturalia Musei Matraensis 30: 407-414.

Simon T., Matus G., Pelles G., Tóth Z. \& VojtKó A. (2007): Növényvilág, növénytani értékek. In: Baráz Cs. \& Kiss G. (szerk.), A Zempléni Tájvédelmi Körzet. - Bükki Nemzeti Park Igazgatóság, Eger.

Soó R. \& HARGITAI Z. (1940): A Sátorhegység flórájáról. - Botanikai Közlemények 37(3-4): 169-187

Soó R. (1943): Előmunkálatok a Bükkhegység és környéke flórájához. - Botanikai Közlemények 40(3-4): $169-221$.

SRAMKó G. \& MAGos G. (2002): A Woodsia ilvensis (L.) R. Br. aktuális helyzete Magyarországon. Botanikai Közlemények 89(1-2): 241.

Szirmai O., Nagy J., Gál B., Czóbel Sz., Szerdahelyi T., Cserhalmi D., Tuba Z. \& Ürmös Zs. (2006): A magyarországi Bodrogköz jellemző vízi és vízparti növénytársulásai. - Folia Historico Naturalia Musei Matraensis 30: 75-89.

TAKÁCS A. \& ZsóLYOMI T. (2011): Adatok a Taktaköz flórájának ismeretéhez. - Kitaibelia 15(1-2): 25-34.

TakÁcs A., Nagy T., Fekete R., Lovas-Kiss Á., Ljubka T., LöKi V., LisZTes-Szabó Zs. \& Molnár V. A. (2014): A Debreceni Egyetem Herbáriuma (DE) I.: A „Soó Rezső Herbárium”. - Kitaibelia 19(1): 142-155.

Takács A., Nagy T., Sramkó G., Lovas-Kiss Á., Süveges K., Lukács B. A., Fekete R., LöKi V., Malatinszky Á., E. VojtKó A., Koscsó J., Pfliegler Walter P., Nótári K. \& MolnÁr V. A. (2016): Pótlások a Magyarország edényes növényfajainak elterjedési atlaszához I. - Kitaibelia 21(1): 101-115.

TAKÁcs A., Schmotzer A. \& SulYok J. (2013): Florisztikai adatok a Sajó-Hernád-sík területéről. Kitaibelia 18(1-2): 73-88.

TAKÁcs A., Süveges K., Ljubka T., LöKi V., Lisztes-Szabó Zs. \& Molnár V. A. (2015): A Debreceni Egyetem Herbáriuma (DE) II.: A „Siroki Zoltán Herbárium”. - Kitaibelia 20: 15-22.

TAKÁCS A., ZÁKÁNY A., GulYÁs G., Koscsó J. \& SRAmKó G. (2014): Florisztikai adatok a Tiszántúl északi pereméről - Kitaibelia 19(2): 275-294.

THAISz L. (1910): Adatok Abaúj-Torna vármegye flórájához. III. közlemény. - Botanikai Közlemények 9(4-5): 222-230.

TuBA Z. (1994): A Bodrogköz növényföldrajza. In: Simon I. \& Boros L. (szerk.), Észak- és KeletMagyarországi Földrajzi Évkönyv. - Miskolc-Nyíregyháza, pp. 187-196. 
Tuba Z., Szirmai O., Nagy J., Czóbel Sz., Cserhalmi D., Gál B., Szerdahelyi T. \& Marschall Z. (2008): A Bodrogköz edényes flórája és annak jellemzői. In: TuBA Z. (szerk.), Bodrogköz. Lórántffy Zsuzsanna Szellemében Alapítvány, Gödöllő-Sárospatak, pp. 477-521.

Türke I.J., Lontay L., SERFőZő J., Zsólyomi T., DROZD A. \& PElles G. (2020): Pótlások Magyarország edényes növényfajainak elterjedési atlaszához XI. Adatok a Tokaj-Zempléni-hegyvidékről és környékéről 25(2): in press.

VAVRinEC M. (2016): Geografické rozšírenie druhov rodu Cirsium na Slovensku. - Universitas Masarykiana Brunensis, PhD thesis, Brno.

VIRÓK V., FARKAS R., FARKAS T., RÓBERT Š. \& VojTKó A. (2016): A Gömör-Tornai-karszt flórája - Enumeráció - ANP füzetek 14. Aggteleki Nemzeti Park Igazgatóság Jósvafó, 200 pp + CD melléklet.

ViróK V., FARKAS R., SZMORAd F. \& Boldoghné SzútS F. (2004): Florisztikai adatok Borsod- AbaújZemplén-megye északi részéről I. - Kitaibelia 9(1): 143-150.

VojтKó A. (2008): Florisztikai adatok Észak-Magyarországról. - Kitaibelia 13(1): 55-61.

WAGNER J. (1922): Néhány újabb adat hazánk flórájához. - Botanikai Közlemények 20(1-3): 84-85.

\section{Világháló oldalak}

[1] https://floraatlasz.uni-sopron.hu/

[2] http://anp.nemzetipark.gov.hu/terinformatika-adatbazis-letoltes

Beérkezett / received: 2019. 03.14. • Elfogadva / accepted: 2019.11. 04. 